\title{
The Essential Role of Vitamin D in the Biosynthesis of Endogenous Antimicrobial Peptides May Explain Why Deficiency Increases Mortality Risk in COVID- 19 Infections
}

\author{
Patrick J McCullough ${ }^{1,4}$, Jeffrey Amend', William P McCullough'2, Steven J. Repas ${ }^{3}$, Jeffrey B. \\ Travers ${ }^{5,6}$ (ORCID 0000-0001-7232-1039) and Douglas S Lehrer ${ }^{4}$ \\ ${ }^{1}$ Summit Behavioral Healthcare, Ohio Department of Mental Health and Addiction Services, 1101 Summit \\ Rd, Cincinnati, OH 45237 \\ ${ }^{2}$ Rose-Hulman Institute of Technology, 5500 Wabash Ave, Terre Haute, IN 47803 \\ ${ }^{3}$ Wright State University Boonshoft School of Medicine, 3640 Colonel Glenn Hwy, Dayton, OH 45435 \\ Departments of ${ }^{4}$ Psychiatry, ${ }^{5}$ Pharmacology \& Toxicology, Wright State University Boonshoft School of \\ Medicine, 3640 Colonel Glenn Hwy, Dayton, OH 45435 \\ 6Dayton Veterans Administration Medical Center, Dayton Ohio \\ *Correspondence: Patrick.mccullough@mha.ohio.gov Tel: 1-513-948-3600
}

\begin{abstract}
A primary action of vitamin D is regulation of gene transcription. Many cell types possess genes that make antimicrobial peptides (AMPS) (endogenous antibiotics), recently discovered to be regulated by vitamin $\mathrm{D}$. Two examples are cathelicidin and beta defensins, both bioactive against many different bacteria, fungi, mycobacteria, parasites and viruses. The signal transduction pathway is triggered by sensing microorganisms via cell surface receptors, causing intracellular production of calcitriol $(1,25(\mathrm{OH}) 2 \mathrm{D})$ and vitamin $\mathrm{D}$ receptors, leading to upregulation of AMP production. Serum $25(\mathrm{OH}) \mathrm{D}$ concentrations required to sustain adequate AMP production to eradicate infections are unknown. Vitamin $\mathrm{D}_{3}$ is photosynthesized in skin in amounts ranging from 10,000 (250 mcg) to 25,000 (625 mcg) International Units (IU) from 7-dehydrocholesterol after wholebody exposure to one minimal erythemal dose (MED) of ultraviolet B (UVB) radiation, and is impacted by many factors including geographic localities, seasonal changes and skin pigmentation. We and others have reported extended daily oral dosing with these amounts of vitamin $\mathrm{D}_{3}$ safe. We routinely observe serum $25(\mathrm{OH}) \mathrm{D}$ concentrations below $20 \mathrm{ng} / \mathrm{ml}$ on new admissions, which have been reported insufficient to sustain AMP production. In contrast serum $25(\mathrm{OH}) \mathrm{D}$ concentrations above $100 \mathrm{ng} / \mathrm{ml}$ have been reported after serial UVB treatments for psoriasis. Little vitamin D naturally occurs in food, and insufficient sun exposure may be causing worldwide deficiency. We review evidence suggesting that higher daily intakes of vitamin $\mathrm{D}_{3}$ than the currently recommended 600 (15 mcg) IU/day may be necessary to sustain AMP production in the face of an overwhelming infection, particularly in non-Hispanic blacks, a high risk population suffering the worst outcomes from COVID-19. We propose that increased vitamin D supplementation could provide a safe and cost-effective way to protect all populations from infections, in particular those from pandemic COVID-19.
\end{abstract}

Keywords: vitamin D; cathelicidin; antimicrobial peptides; bacteria; mycobacteria; virus; coronavirus; sunshine; UVB phototherapy; tuberculosis; COVID-19; photosynthesis 


\section{Introduction}

Vitamin D was named a vitamin after being discovered in the 1920s when it was isolated from both cod liver oil and the skin of laboratory animals subjected to UVB radiation [1-3]. It was found to be made from 7-dehydrocholesterol in the skin, and its chemical structure was determined to be a steroid in the 1930s [2]. In the 1960s it was shown that two hydroxylation reactions were required to form the active hormone form of vitamin $\mathrm{D}_{3}$ (1,25-dihydroxyvitamin $\mathrm{D} 3,(1,25(\mathrm{OH}) 2 \mathrm{D} 3)$, or calcitriol) from the preprohormone vitamin $\mathrm{D}_{3}$ (cholecalciferol). The structure of the vitamin $\mathrm{D}$ receptor (VDR) was also determined, and the VDR was found to be in the same family of other steroid hormone receptors [2-3].

Vitamin $\mathrm{D}$ exists in 2 forms, vitamin $\mathrm{D}_{2}$ and vitamin $\mathrm{D}_{3}$, which differ chemically by alterations in the side chain carbons coming off the fourth steroid ring. Vitamin $\mathrm{D}_{2}$ (calciferol, or ergocalciferol) was shown to have "antimicrobial" properties in the 1940s when it was found to successfully treat chronic mycobacterium tuberculosis (TB) infections of the skin known as lupus vulgaris [4-11]. Previously cod liver oil [12], UVB phototherapy [11,13-17] and sunshine [18-19] were reported to be effective treatments for TB infections. In 1903 the Nobel Prize in Medicine or Physiology was awarded to a scientist, Dr Neils Ryberg Finsen, for curing hundreds of cases of lupus vulgaris with refracted light rays from an electric arc lamp between the years of 1895 and 1901 [13-14]. UVB phototherapy and sunshine soon became the mainstays of treatment for tuberculosis infections until the advent of antibiotics in the 1940s [15-19].

In the 1940s scientists tested the hypothesis that oral vitamin D alone could be effective in treating chronic TB infections for several reasons. First, it was known that sunshine and UVB phototherapy caused the formation of vitamin D in the skin. Second, vitamin D was present in cod liver oil. Third, sunshine, UVB phototherapy and cod liver oil were all effective treatments for TB infections. Finally, because treatment with UVB phototherapy was expensive and cumbersome, they were looking for an easier alternative treatment. As one scientist, Lieut.-Colonel F.F. Heller, pointed out in 1946 "It would now appear that we have constructed our wonderful light equipment, our Kromayer, our Finsen-Reyn lamps, merely for the sake of applying a dose of calciferol to the skin, when it could have been given more readily by the mouth [6] (p. 226)".

The rationale for how these investigators chose the doses they used is not clear. However, daily intake of oral vitamin $\mathrm{D}_{2}$ in doses ranging from 100,000 (2500 mcg) IU/day to 150,000 $(3750 \mathrm{mcg}$ ) IU/day for 2 to 3 months was so successful in safely eradicating long-standing TB infections in the 1940s [4-11] that it led one author, Dr Dowling, to state "these five cases, together with the six who were presented to the section on November 15, and a considerable number of others which have responded in a similar way to the same treatment, can leave no room for doubt that calciferol in adequate dosage will cure a substantial proportion of cases of lupus. The question that must interest us now is, how does it act? [6] (p. 226)." (Note: one microgram of vitamin D is equivalent to $40 \mathrm{IU}$ ).

Several other microorganisms besides mycobacterium tuberculosis were also found to be susceptible to vitamin $\mathrm{D}_{2}$ in the 1940s [4]. These included proteus vulgaris, bacillus aerogenes, staphylococci and non-hemolytic streptococci. Vitamin D was shown to be effective at killing these microorganisms both in patients and in petri dishes, leading Dr. Raab, the author who discovered and reported this while treating patients with pulmonary tuberculosis, to conclude "Therefore, it can be stated that vitamin $\mathrm{D}$ is a bactericidal, bacteriostatic and bacteria lytic substance in vivo and in vitro [4] (p. 409]."

The answer to the question "How does it act?" came 60 years later when several investigators showed that calcitriol induces expression of the antimicrobial peptides cathelicidin and beta defensins [20-22]. Subsequently, it was shown that "toll -like receptor activation of human macrophages upregulated expression of the vitamin D receptor and the vitamin D-1-hydroxylase genes, leading to induction of the antimicrobial peptide cathelicidin and killing of intracellular mycobacterium tuberculosis [23] (p. 1770)," which offers an explanation of the mechanism of action of vitamin D in eradicating tuberculosis infections.

During the past 2 decades research on how vitamin $D$ regulates genes, how it is triggered to turn on and turn off genes, and the identity of several gene products and their physiological roles in the 
body has been very active [1-3,20-47]. We now know that several different antimicrobial peptides are produced by genes regulated by vitamin D. These antimicrobial peptides include cathelicidin, defensins, S100 proteins, ribonucleases (RNases) and dermcidin, which have shown bioactivity against multiple microorganisms, including fungi, parasites and viruses, in addition to bacteria and mycobacteria [20-43].

In this review, we will summarize key discoveries in these reports made between 2004 to 2020, as there is a strong correlation between vitamin D deficiency and risk for acute respiratory infections such as COVID-19 [48-51]. We will first discuss important aspects of vitamin D and the human genome [1-3, 44-47,52-54] and review a 2019 report describing a significant dose response relationship between vitamin $\mathrm{D}$ intake and gene regulation [55].

Two major vitamin D supplementation guidelines published in 2011 [56-57 vs 58] will then be discussed, highlighting important differences between them, and how both guidelines likely significantly impact the ability of vitamin $\mathrm{D}$ to adequately regulate the many genes it is responsible for controlling, by advising daily intake of what appear to be insufficient amounts of vitamin D.

We will discuss key findings from our experiences in treating several thousand hospitalized patients with 5000 (125 mcg) IU/day to $10,000(250 \mathrm{mcg}) \mathrm{IU} /$ day of vitamin $\mathrm{D}_{3}$ as a standard of care for the past 11 years to correct and prevent deficiency, as well as higher doses ranging up to 50,000 (1250 mcg) IU/day to 60,000 (1500 mcg) IU/day in several individuals for specific disease related reasons, which have been effective without causing hypercalcemia or other adverse events [59].

We will review several unique aspects of vitamin D as a steroid hormone precursor, how it is available in both prescription and over the counter (OTC) formulations as well as in a small number of foods, and caveats to be aware of in choosing an OTC supplement due to the differing manufacturing standards of prescription medications versus OTC supplements [60-61].

Finally, we will review two recent analyses of racial disparities in serum $25(\mathrm{OH}) \mathrm{D}$ concentrations, which found non-Hispanic (NH) blacks to have significantly higher rates of vitamin D deficiency of any race [62-63], and discuss how this may explain why they are suffering the worst outcomes among those infected with COVID-19 [64-65]. We will discuss why daily intake of vitamin D in amounts higher than currently recommended may be necessary to sustain adequate AMP production in response to infection, and how this may be helpful in dealing with the coronavirus pandemic. This, and latitude associations of viral pandemics resulting in lower levels of UVB radiation also could fit with altered serum $25(\mathrm{OH})$ D concentrations. We hypothesize that VDR activation status could be playing an important role in the infectivity of viruses such as COVID-19.

\section{Vitamin $\mathrm{D}$ and the human genome}

In 2003 the Human Genome Project estimated that there are about 20,500 protein coding genes in human DNA [52-53]. In 2010 Ramagopalan and colleagues identified 2776 VDR binding sites in the DNA in lymphoblastoid cell lines from CEPH individuals (GM10855 and GM10861) from the International HapMap Project after stimulation with calcitriol, and 229 with significant changes in response to vitamin D [54].

Thus, recent data indicates that a significant percentage of our genes are regulated by vitamin D. It is also significant that several of the VDR binding sites were noted to be significantly enriched near genes associated with cancer and several autoimmune diseases such as Crohn's disease, type 1 diabetes, multiple sclerosis and systemic lupus erythematosus, as these diseases have all been strongly linked to vitamin D deficiency [57-59,62-63,66]. Moreover, vitamin D was first shown in the 1930s and 1940s to be an effective treatment for the autoimmune diseases psoriasis [67] and rheumatoid arthritis [68-70], and since 1986 has been routinely used to safely treat psoriasis using both oral [59,71-85] and topical formulations [86-97], as has sunshine and UVB phototherapy [67,98120]. Several reviews have been written on the use of vitamin $D$ in treating psoriasis [121-127].

Reports describing how vitamin D interacts with the VDR, and how it requires other transcription factors to bind along with it, such as the retinoid $X$ receptor, prior to binding to a specific area in the DNA called the vitamin D response element (VDRE), also started appearing in the 2000s [1-3,20-47]. Several reviews on the genetic actions of vitamin D have indicated that the VDR mediates 
virtually all of the known biological actions of calcitriol [2-3,44-47]. Once the VDR binds to the regulatory regions of vitamin $\mathrm{D}$ dependent genes in the nucleus of cells, modulation of their transcriptional output occurs with either up-regulation or down-regulation of the genes. Technological advances have enabled scientists to advance our knowledge in this area by allowing them to study transcription factor binding on a genome-wide scale in cells and tissues that are major targets of vitamin D action [44-47,54].

More recently, a landmark study reported in 2019 that the number of genes up or down regulated in human white blood cells (WBCs) is dependent on the daily dose of vitamin D ingested, with a significantly greater number of genes either up or down regulated observed with higher daily intakes of vitamin $\mathrm{D}_{3}$ after a 6-month period of supplementation [55]. In this study three groups of healthy volunteers took either $600(15 \mathrm{mcg}) \mathrm{IU} /$ day $(\mathrm{n}=10), 4000(100 \mathrm{mcg}) \mathrm{IU} / \mathrm{day}(\mathrm{n}=13)$ or 10,000 $(250 \mathrm{mcg}) \mathrm{IU} /$ day $(\mathrm{n}=10)$ of vitamin $\mathrm{D}_{3}$ for 6 months. At the end of the study, a dose dependent 25(OH)D alteration in broad gene expression was observed with 162, 320, and 1289 genes either up or down regulated in their white blood cells respectively. Mean serum 25(OH)D concentrations at baseline were $17 \mathrm{ng} / \mathrm{ml}$ for the 33 individuals. At 24 weeks the mean serum 25(OH)D concentrations in the three groups were $24.3 \mathrm{ng} / \mathrm{ml}(600(15 \mathrm{mcg}) \mathrm{IU} /$ day $), 40.8 \mathrm{ng} / \mathrm{ml}(4000$ (100 mcg) IU/day) and $78.6 \mathrm{ng} / \mathrm{ml}(10,000(250 \mathrm{mcg}) \mathrm{IU} /$ day). No significant differences were observed in serum calcium concentrations in any group. Serum parathyroid hormone (PTH) concentrations were unchanged in the 600 (15 mcg) IU/day group, but significantly decreased by week 16 in the 4000 (100 mcg) IU/day group by $17 \%$, and by $33.3 \%$ in the $10,000(250 \mathrm{mcg}) \mathrm{IU} /$ day group and remained there for the remaining eight weeks of the study. Vitamin $\mathrm{D}_{3}$ intake of 10,000 $(250 \mathrm{mcg}) \mathrm{IU} /$ day produced genomic alterations eight times higher than observed in the group taking $600(15 \mathrm{mcg}) \mathrm{IU} /$ day, and four time higher than observed in the $4000(100 \mathrm{mcg})$ IU/day group. The authors concluded that "Our findings may help explain why there are some inconsistencies in the results of different vitamin D clinical trials [55] (p. 1)."

One plausible explanation for the potential lack of effects noted in vitamin D clinical trials is that many clinical trials with vitamin $\mathrm{D}$ in the past 30 years have typically used intakes of vitamin $\mathrm{D}$ substantially below 10,000 (250 mcg) IU/day [50-51,58,128] and achieved serum 25(OH)D concentrations much lower than those observed in the 10,000 (250 mcg) IU/day group [58]. The serum $25(\mathrm{OH}) \mathrm{D}$ concentrations observed in the 10,000 $(250 \mathrm{mcg}) \mathrm{IU} /$ day group are consistent with other reports that used prolonged daily intake of 10,000 (250 mcg) IU/day [59,129]. They are also consistent with $25(\mathrm{OH}) \mathrm{D}$ concentrations observed after UVB phototherapy treatment of psoriasis, where serum 25(OH)D concentrations > $100 \mathrm{ng} / \mathrm{ml}[99,106-108]$, and as high as $159 \mathrm{ng} / \mathrm{ml}$ have been reported [99]. UVB radiation is also known to generate $10,000(250 \mathrm{mcg})$ to $25,000(625 \mathrm{mcg}) \mathrm{IU} /$ day of vitamin $\mathrm{D}_{3}$ in the skin after exposure to 1 MED of UVB radiation [58].

The daily doses of vitamin $\mathrm{D}_{3}$ used in this study are directly from updated dietary reference intake recommendations for vitamin D published in 2011 by two authoritative agencies. One was the Institute of Medicine (IOM) [56-57] (now known as the Health and Medicine Division of the National Academies); the second was the Endocrine Society [58]. Due to significantly greater vitamin D dependent genes being regulated with 10,000 (250 mcg) IU/day of vitamin $\mathrm{D}_{3}$ than with either 600 (15 $\mathrm{mcg}) \mathrm{IU} /$ day or $4000(100 \mathrm{mcg}) \mathrm{IU} /$ day, it raises potential concerns about the appropriateness of current vitamin $\mathrm{D}$ daily intake recommendations by both organizations.

\section{Current recommendations for daily intake of vitamin $D$ and sun exposure}

In 2011 the IOM published updated “Dietary reference intakes for calcium and vitamin D" [57], which were previously revised in 1997 [130]. They stated that daily intake of 600 (15 mcg) IU of vitamin $\mathrm{D}_{3}$ would be sufficient for most adults ages 18 to 70, and $800(20 \mathrm{mcg})$ IU for adults older than 70 (p. 9). The IOM set their recommended daily allowance of vitamin D at 600 (15 mcg) IU, the tolerable upper intake level at 4,000 (100 mcg) IU/day, and the no adverse effects level (NOAEL) at 10,000 (250 mcg) IU/day for most adults. The IOM also stated "Practically all persons are sufficient at serum $25 \mathrm{O}(\mathrm{H}) \mathrm{D}$ levels of at least $50 \mathrm{nmol} / \mathrm{L}(20 \mathrm{ng} / \mathrm{mL})$. Serum $25(\mathrm{OH}) \mathrm{D}$ concentrations above 75 
$\mathrm{nmol} / \mathrm{L}(30 \mathrm{ng} / \mathrm{mL})$ are not consistently associated with increased benefit. There may be reason for concern at serum 25(OH)D levels above $125 \mathrm{nmol} / \mathrm{L} \mathrm{(50} \mathrm{ng/mL)} \mathrm{[57]} \mathrm{(p.} \mathrm{14)."}$

In 2011 the Endocrine Society published a competing set of guidelines in response to those issued by the IOM, entitled "Evaluation, treatment, and prevention of vitamin D deficiency: An Endocrine Society clinical practice guideline [58]." The recommendations from the Endocrine Society (ES) were similar but differed significantly from those of the IOM in several areas. First, the ES defined deficiency as serum $25(\mathrm{OH}) \mathrm{D}$ concentrations less than $20 \mathrm{ng} / \mathrm{ml}$, and insufficiency as $<30 \mathrm{ng} / \mathrm{ml} \mathrm{but}>$ $20 \mathrm{ng} / \mathrm{ml}$. The ES stated that while serum $25(\mathrm{OH}) \mathrm{D}$ concentrations $>20 \mathrm{ng} / \mathrm{ml}$ were necessary to prevent rickets and osteomalacia, they needed to be $>30 \mathrm{ng} / \mathrm{ml}$ to "maximize vitamin D's effect on calcium, bone and muscle metabolism [58] (p. 22)" and may have additional health benefits in reducing the risk for many other diseases linked to vitamin D deficiency, including "common cancers, autoimmune diseases, type 2 diabetes, cardiovascular disease, and infectious diseases [58] (p. 22)."

Second, the ES also recommended higher daily intake of vitamin D in patients at risk for vitamin D deficiency than the IOM. Compared to the IOM, the ES recommended:

a) 400 (10 mcg) to 1000 (25 mcg) IU in infants vs 400 (10 mcg) IU by the IOM;

b) 600 (15 mcg) to 1000 (25 mcg) IU for ages 1 to 18 vs 600 (15 mcg) IU by the IOM;

c) 1500 (37.5 mcg) to 2000 (50 mcg) IU for ages 19 and older, vs 600 (15 mcg) IU to age 70 and 800 (20 mcg) IU for over age 70 by the IOM.

d) higher daily intakes for people suffering from obesity, and for people taking anticonvulsant medications, glucocorticoids, antifungals and medications for AIDS. These groups will likely require at least $6000(150 \mathrm{mcg})$ to 10,000 (250 mcg) IU treat vitamin D deficiency and maintain a serum $25(\mathrm{OH}) \mathrm{D}$ concentration above $30 \mathrm{ng} / \mathrm{ml}$.

e) The ES also recognized that it was unknown if intakes of 400 (10 mcg) IU, 600 (15 mcg) IU and 800 (20 mcg) IU were enough to provide all the nonskeletal health benefits associated with vitamin D vs the IOM's statement that nearly everyone is sufficient with a serum $25(\mathrm{OH}) \mathrm{D}$ concentration above $20 \mathrm{ng} / \mathrm{ml}$.

Third, the ES recommended higher maintenance tolerable upper intake levels (UL) in almost all age groups:

a) 2000 (50 mcg) IU for 0 to 6 and 6 to 12 months vs 1000 (25 mcg) IU and 1500 (37.5 mcg) IU by the IOM;

b) 4000 (100 mcg) IU for ages 1 to 3 and 4 to 8 vs 2500 (62.5 mcg) IU and 3000 (75 mcg) IU by the IOM;

c) 4000 (100 mcg) IU for ages 9 to 18 vs 4000 (100 mcg) IU by the IOM

d) 10,000 (250 mcg) IU in ages 19 and older, vs 4000 (100 mcg) IU in ages 9 and older by the IOM. A comparison of the recommendations of the two groups for infants, children, males, females, pregnancy and lactation is provided in table 3 of the report (p. 12).

The assessment that the maintenance tolerable upper intake level of 10,000 (250 mcg) IU/day of vitamin D for adults 19 years and older was reasonable, as opposed to the 4000 (100 mcg) IU/day limit set by the IOM, is a very important difference. The Tolerable Upper Intake Level (UL) is the highest level of daily nutrient intake that is likely to pose no risk of adverse health effects to almost all individuals in the general population, and per the ES " is not to be exceeded without medical supervision [58] (p. 18)." They also stated that this intake may be necessary at times to correct deficiency and to maintain serum $25(\mathrm{OH}) \mathrm{D}$ concentrations above $30 \mathrm{ng} / \mathrm{ml}$, particularly in obese patients. This recommendation for the UL was based in part on a dose-ranging study from 2003 that reported men who received either 5500 (137.5 mcg) IU/day or 11,000 (275 mcg) IU/day of vitamin D3 for 5 months did not experience any alteration in either serum calcium or urinary calcium excretion, or any other adverse effects related to vitamin D intake [129]. A total of 67 healthy subjects were enrolled in the study. Both groups showed significant increases in serum $25(\mathrm{OH}) \mathrm{D}$ concentrations after 5 months. Mean serum 25(OH)D concentrations at baseline were 28ng/ml, and after 5 months increased to $64 \mathrm{ng} / \mathrm{ml}$ in the $5500(137.5 \mathrm{mcg}) \mathrm{IU} /$ day group, and 88ng/ml in the 11,000 (275 mcg) 
IU/day group, while only a 5ng/ml increase was observed in a group taking 836 (20.9 mcg) IU/day, and a $5 \mathrm{ng} / \mathrm{ml}$ drop was observed in a placebo group.

The Endocrine Society also recognized that exposure to sunlight or UVB radiation generates " 20,000 IU of vitamin $\mathrm{D}_{3}$ in the skin, equivalent to exposure to 1 minimal erythemal dose (MED) in a bathing suit. Thus, exposure of arms and legs to 0.5 MED is equivalent to ingesting $~ 3,000$ IU vitamin $\mathrm{D}_{3}$ [58] (p. 9)." "When an adult wearing a bathing suit is exposed to one minimal erythemal dose of UV radiation (a slight pinkness to the skin $24 \mathrm{~h}$ after exposure), the amount of vitamin D produced is equivalent to ingesting between 10,000 and 25,000 IU [58] (p. 7)." Consistent with this notion, the Endocrine Society also noted that "the major source of vitamin D for children and adults is exposure to natural sunlight $(3,7,35-37)$. Very few foods naturally contain or are fortified with vitamin D. Thus, the major cause of vitamin D deficiency is inadequate exposure to sunlight [58] (p. 7)."

The IOM, on the other hand, never acknowledged in their report the amounts of vitamin $\mathrm{D}_{3}$ estimated to be made in the skin from exposure to 1 MED in a bathing suit, or how 600 (15 mcg) IU/day could be sufficient if the body makes up to 25,000 (625 mcg) IU/day in response to sun exposure. They also concluded "For vitamin D, the challenges introduced by issues of sun exposure are notable. This nutrient is unique in that it functions as a hormone and the body has the capacity to synthesize it. However, concerns about skin cancer risk preclude incorporating the effects of sun exposure in the DRI process. At this time, the only solution is to proceed on the basis of the assumption of minimal sun exposure and set reference values assuming that all of the vitamin $\mathrm{D}$ comes from the diet [57] (p. 12)."

While these concerns regarding sun exposure appear noble, the IOM also never reconciled these concerns with other important information that was available prior to the publication of their 2011 report; such as the fact sunshine and UVB phototherapy were well documented treatments for treating TB infections [11,13-19] and rickets [131-132], and were also well documented treatments for safely controlling the plaques that form on the skin in the autoimmune disease psoriasis [98-120]. Sunshine and UVB phototherapy are recommended as treatments for psoriasis by the National Psoriasis Foundation [120] and the American Academy of Dermatology [105] and have been for many years prior to 2011. As discussed earlier, several UVB phototherapy reports showed that serum $25(\mathrm{OH}) \mathrm{D}$ concentrations rose much higher than $50 \mathrm{ng} / \mathrm{ml}$ after successful treatment of psoriatic skin plaques without causing adverse events [99,106-108]. Also as discussed earlier, both oral and topical vitamin D have also been shown to be safe and effective treatments for psoriasis [71-97], and several reviews on this topic have been written [121-127]. It is interesting to note that baseline serum 25(OH)D concentrations reported in oral vitamin D [71-85] and UVB phototherapy [99,106-108] studies were often above $20 \mathrm{ng} / \mathrm{ml}$, ranging to as high as $80 \mathrm{ng} / \mathrm{ml}$, many of which would be considered normal by either the IOM, the ES, or both, yet the subjects' psoriasis still improved with treatment.

We mention this because the IOM stated in their 2011 report the only proven health benefits for vitamin D were in certain bone diseases and listed many other diseases which they classified as diseases of interest, but for which the data were insufficient to conclude a proven benefit from vitamin D supplementation [57]. Many diseases were on this list, including asthma, rheumatoid arthritis, tuberculosis and several other autoimmune diseases, but not psoriasis.

"Box S-2 lists these potential indicators in alphabetical order. The close inter-relationship between calcium and vitamin $\mathrm{D}$ often resulted in potential indicators being relevant to both nutrients [57] (p.3)." "In sum, with the exception of measures related to bone health, the potential indicators examined are currently not supported by evidence that could be judged either convincing or adequate in terms of cause and effect, or informative regarding dose-response relationships for determining nutrient requirements [57] (p.5)."

There is no discussion about psoriasis in the IOM report, and it is also not mentioned or discussed in the Endocrine Society report. Moreover, neither the IOM nor the Endocrine Society mention the studies from the 1940s that showed that tuberculosis was effectively treated with oral vitamin $\mathrm{D}_{2}$ [4-11], or the reports from the 1930s showing that vitamin $\mathrm{D}_{2}$ was used effectively in treating rheumatoid arthritis [68-70] and asthma [133], in addition to psoriasis. 
The conclusions and recommendations made by the IOM and the Endocrine Society in 2011 must be reconsidered in light of arguments based upon data presented in this report and the recent dose response findings [55]. This recalibration of effective vitamin D intake recommendations is especially true if we are going to be able to mount an effective endogenous antimicrobial peptide response when cells are triggered to turn on vitamin D regulated genes and produce sufficient quantities of the antimicrobial peptides described in the next section.

Without a sufficient serum $25(\mathrm{OH}) \mathrm{D}$ concentration, an adequate response will be difficult to sustain. And this may have severe implications for the public health during the current coronavirus pandemic.

\section{Vitamin D generates antimicrobial peptides active against numerous microorganisms, and vitamin $\mathrm{D}$ deficiency is strongly linked to risk for acute respiratory infections.}

In 2004 and 2005, several groups of investigators discovered that calcitriol induces the expression of the antimicrobial peptides cathelicidin and defensin beta2 in vitamin D regulated genes by binding to a unique area of the DNA identified as the vitamin D response element [20-22]. Prior to this the mechanism as to how these genes were regulated was unknown. Multiple cell types were shown to produce antimicrobial peptides in these three reports, including human keratinocytes, monocytes, and neutrophils, and human cell lines [20], acute myeloid leukemia (AML), immortalized keratinocytes, colon cancer cells, normal human bone marrow (BM) derived macrophages, and fresh BM cells from two normal individuals and one AML patient [21], and leukocytes, epithelia surfaces, and in the basal layer of keratinocytes [22]. Cathelicidin had previously been identified to be secreted in significant amounts in the squamous epithelia of the mouth, tongue, esophagus, lungs, intestine, cervix, vagina, salivary and sweat glands, epididymis, testis and mammary glands, but the mechanism of its production was unknown [21]. These studies showed for the first time that induction of transcription of the antimicrobial peptide gene required binding of calcitriol and its receptor to a specific area of DNA referred to as the promoter region of the gene, which for vitamin $\mathrm{D}$ is the VDRE.

Subsequently in 2006 it was shown in a study investigating tuberculosis and white blood cells that the triggering of toll-like receptors (TLRs) on the cell surface of human macrophages by tuberculosis protein caused the upregulation of genes leading to the production of the vitamin $\mathrm{D}$ receptor and the vitamin D-1-hydroxylase enzyme [23]. This is the enzyme that converts circulating $25(\mathrm{OH}) \mathrm{D}$ into calcitriol on demand inside of the cells. This was then shown to lead to the upregulation of vitamin $\mathrm{D}$ regulated genes that made the antimicrobial peptide cathelicidin and the killing of intracellular Mycobacterium tuberculosis. They also made the following very important observation "...that sera from African-American individuals, known to have increased susceptibility to tuberculosis, had low 25-hydroxyvitamin D and were inefficient in supporting cathelicidin messenger RNA induction. These data support a link between TLRs and vitamin D-mediated innate immunity and suggest that differences in ability of human populations to produce vitamin D may contribute to susceptibility to microbial infection [23] (p. 1770)." In this report, it appears that the mean serum 25(OH)D concentrations were $10 \mathrm{ng} / \mathrm{ml}$ in African Americans versus $30 \mathrm{ng} / \mathrm{ml}$ in Caucasians (Fig 4D, p. 1773).

These observations offer a plausible explanation as to why cod liver oil, sunshine, UVB phototherapy, and oral vitamin D resulted in dramatic improvements in treating chronic tuberculosis infections in the 1800s through the 1940s. People suffering from the chronic TB infections were likely vitamin D deficient and unable to mount an effective antimicrobial peptide response until their vitamin D deficiency state was corrected.

We may be seeing history repeat itself now with the coronavirus pandemic. We will review data in section 7 showing that non-Hispanic blacks are significantly more deficient in vitamin D [62-63] and are suffering more serious complications and deaths from coronavirus infections than other groups [64-65]. This correlation fits with a number of recent reports which have shown that vitamin D plays a role regulating the immune response against viral infections [30-31,34,36-41], and that deficiency confers increased susceptibility to respiratory infections [48-51]. 
Since 2004 antimicrobial peptides have been found to kill a wide variety of microorganisms, including many different bacteria, fungi, mycobacteria, parasites and viruses [20-43]. Two recent reports on the dengue virus showed a dose response effect, with 4000 (100 mcg) IU of vitamin D being more effective than 1000 (25 mcg) IU in killing dengue virus [38,41]. In a recent report on HIV infections, investigators showed that vitamin D may be a good adjuvant to cART (combination antiretroviral therapy). Efficacy of the vitamin D combined with antiretroviral therapy was found to depend on the dose and duration of the treatment. Dosages which showed the most success were 4000 (100 mcg) IU and 7000 (175 mcg) IU given daily for at least 12 weeks. Studies with larger sample sizes were recommended to confirm the beneficial effects of vitamin $D$, and to establish optimal supplementation and maintenance doses in the context of HIV-1 infection [39].

Several other viral infections have been linked to vitamin D. For example, a recent report on rotavirus showed a strong link with vitamin D deficiency [34], while a later report showed that vitamin D can alleviate rotavirus infections [40]. A report in 2013 showed that cathelicidin has antiviral activity against respiratory syncytial virus [31], while a report from 2018 showed that cathelicidin disrupts the Kaposi's sarcoma-associated herpesvirus envelope and inhibits infection in oral epithelial cells [36]. The results of a recently reported community field trial indicated that serum $25 \mathrm{OHD}$ concentrations $>50 \mathrm{ng} / \mathrm{ml}$ compared to $<20 \mathrm{ng} / \mathrm{ml}$ were associated with a $27 \%$ reduction in influenza-like illnesses [48]. Other investigators have also concluded that a significant body of work suggests that the current RDA for vitamin D is unlikely to raise serum $25(\mathrm{OH}) \mathrm{D}$ concentrations to levels needed for adequate function of the immune system [43].

It is also known that small changes in VDR alleles that affect activity can influence the susceptibility or resistance to infection. For example, a study of Canadian children has reported that VDR gene polymorphisms increase the likelihood of acute lower respiratory tract infections [134]. Several lines of evidence have also suggested an important role for VDR signaling in hand, foot and mouth disease (HFMD) caused by coxsackievirus A16. Serum 25(OH)D concentrations in HFMD patients are lower than in healthy uninfected controls [135]. A significant relationship has been reported between VDR single nucleotide polymorphisms (SNP) that result in decreased activity with HFMD infection susceptibility [136]. Thus, genetic analysis supports the concept that vitamin D deficiencies can influence viral pathogenesis.

In addition to their killing activities, antimicrobial peptides have also been found to display immunomodulatory properties, including induction of cell migration, proliferation and differentiation; regulation of cytokine/chemokine production; promotion of angiogenesis and wound healing; and maintenance of the barrier function of the skin [21,22,25,26,35,38].

Once a cell is triggered by microorganisms interacting with toll-like receptors on its surface, increased production of the VDR and the enzyme 25-hydroxyvitamin D 1-alpha hydroxylase (which converts circulating 25(OH)D into calcitriol intracellularly) are seen [23]. Calcitriol is then made on demand inside cells from circulating $25(\mathrm{OH}) \mathrm{D}$ by an enzymatic reaction that places a second hydroxyl group on the first carbon of the first steroid ring. Calcitriol then binds with the VDR and multiple other transcription factors, and the whole complex then binds to the VDRE, enabling the upor down- regulation of vitamin D regulated genes, some of which make antimicrobial peptides able to kill multiple microorganisms [1-3,20-45]. Thus, the reports that supplementation with the very high doses of vitamin D used in the 1940s are effective in treating tuberculosis infections [4-11], could be due to increased AMP production.

Future relevant areas of investigation will be determining the minimal daily vitamin $\mathrm{D}$ intake or UVB exposure times and serum $25(\mathrm{OH}) \mathrm{D}$ concentrations that are necessary to sustain antimicrobial peptide production sufficiently to eradicate an infection without causing hypercalcemia to occur.

It is reassuring that neither sunshine nor UVB phototherapy have been reported to cause hypercalcemia, in spite of causing the body to make 10,000 (250 mcg) IU to 25,000 (625 mcg) IU of vitamin $\mathrm{D}_{3}$ a day. And both treatments have been proven to be effective intreating TB infections, rickets and psoriasis, as has oral vitamin D.

A strong argument can be made that taking daily doses in this range is not only likely to be safe, which is consistent with our experience [59] and that of others [55,85,129,137-140], but will also 
sustain AMP production long enough to eradicate an infection. We will discuss our experience in using these doses for extended periods of time and the serum $25(\mathrm{OH}) \mathrm{D}$ concentrations we observed in section 6, but will first review several important aspects of currently available sources of vitamin D.

\section{Vitamin $\mathrm{D}$ is a steroid hormone precursor available in prescription and OTC formulations}

Vitamin $\mathrm{D}_{3}$ (cholecalciferol) and vitamin $\mathrm{D}_{2}$ (ergocalciferol) are steroid hormone precursors. After vitamin $\mathrm{D}_{3}$ is formed in the skin or ingested from a food source or supplement, two hydroxylation reactions occur which convert cholecalciferol into $25(\mathrm{OH}) \mathrm{D}_{3}$ (calcidiol) and then into $1,25(\mathrm{OH}) 2 \mathrm{D}_{3}$ (calcitriol). Calcidiol has a relatively stable half-life in the blood of 2 to 3 weeks and is what is measured to determine a person's vitamin D status. It is a prohormone. Calcitriol has a halflife on the order of a few hours and is the active steroid hormone form of vitamin $\mathrm{D}_{3}$. The same reactions occur with $\mathrm{D}_{2}$ to transform it into the active steroid hormone form, $1,25(\mathrm{OH}) 2 \mathrm{D}_{2}$.

Calcitriol is a steroid hormone [44]. Steroid hormones are made from cholesterol, while peptide hormones are made from amino acids. Examples of peptide hormones and where they are made include insulin (pancreas), oxytocin (brain), antidiuretic hormone (brain), and growth hormone (pituitary gland). Examples of steroid hormones include estrogen (ovaries), testosterone (testes), cortisol (adrenal gland) and vitamin D (skin).

Vitamin D is also unique in several important ways from other hormone precursors.

First, both vitamin $\mathrm{D}_{3}$ and vitamin $\mathrm{D}_{2}$ are present naturally in small amounts in a few food sources, mainly oily fish for vitamin $\mathrm{D}_{3}$, and mushrooms and egg yolks for vitamin $\mathrm{D}_{2}[58,66]$. Second, our bodies can synthesize vitamin $\mathrm{D}_{3}$, but not vitamin $\mathrm{D}_{2}$, from 7-dehydrocholesterol in the skin and require exposure to sunshine for this to happen, specifically the UVB spectrum (280 to $320 \mathrm{~nm}$ wavelength) of sunlight. Vitamin $\mathrm{D}_{2}$ is manufactured through the ultraviolet irradiation of ergosterol from yeast and is not produced in the body [66].

Third, we obtain very little vitamin $\mathrm{D}$ from the diet in comparison to the amounts of $\mathrm{D}_{3}$ generated in the skin from exposure to sunshine or UVB phototherapy, which are 10 to 250 times higher. For example, fresh wild salmon ( $3.5 \mathrm{oz})$ contains about 600 (15 mcg)-1000 (25 mcg) IU of vitamin $\mathrm{D}_{3}$, fresh shitake mushrooms ( $3.5 \mathrm{oz}$ ) contain about $100(2.5 \mathrm{mcg})$ IU of vitamin $\mathrm{D}_{2}$, egg yolk contains about 20 $(0.5 \mathrm{mcg}) \mathrm{IU}$ of vitamin $\mathrm{D}_{3}$ or $\mathrm{D}_{2}$, and cod liver oil (1 tsp) contains about $400(10 \mathrm{mcg})-1000(25 \mathrm{mcg})$ IU of vitamin $\mathrm{D}_{3}[58,66]$. In contrast, whole body sun exposure causes 10,000 (250 mcg) IU to 25,000 ( $625 \mathrm{mcg}$ ) IU of vitamin $\mathrm{D}_{3}$ to be formed [58]. Lack of adequate sun exposure to our skin is viewed by the ES the single biggest cause of vitamin D deficiency [58] and is likely affecting a significant percentage of the world's population. Our bodies are designed to make vitamin $\mathrm{D}_{3}$ from sun exposure to our skin in amounts far greater than those available in the few dietary sources from which $\mathrm{D}_{3}$ and $\mathrm{D}_{2}$ naturally available.

Vitamin $\mathrm{D}$ is available in a prescription form as vitamin $\mathrm{D}_{2}$, and as over the counter supplements (OTCs) as vitamin $\mathrm{D}_{3}$. Vitamin $\mathrm{D}_{3}$ is available in various strengths, ranging from 400 (10 mcg) IU/pill to $10,000(250 \mathrm{mcg}) \mathrm{IU} /$ pill, while vitamin $\mathrm{D}_{2}$ is available in the prescription formulation with a concentration of 50,000 (1250 mcg) IU per capsule. The concentration of vitamin D supplements has traditionally been expressed in IUs but is now moving to micrograms (mcg). One microgram is equivalent to $40 \mathrm{IU}$; ten mcg is $400 \mathrm{IU}$; one hundred mcg is $4000 \mathrm{IU}$; and one thousand mcg is 40,000 IU. The intake doses in this manuscript are expressed with both units to familiarize the reader with the new standard.

Prescription medications are regulated by the Food and Drug Administration (FDA), while OTC supplements, which are considered dietary supplements, are not. Manufacturing and labeling errors are commonly encountered in dietary supplements [60], and several OTC formulations of vitamin D3 have led to serious complications from accidental overdosing due to such errors [61]. As a result, it would be prudent to consider using only United States Pharmacopeia (USP) verified OTC vitamin D3 supplements, of which only three are currently available [141]. USP verification is an extra cost to the manufacturer, but indicates that the product contains the ingredients listed on the label, in the declared potency and amounts; does not contain harmful levels of specified contaminants; will break 
down and release into the body within a specified amount of time; and has been made according to FDA current Good Manufacturing Practices using sanitary and well-controlled procedures.

\section{Insights from our 11 year experience in treating hospitalized patients with 5000 (125 mcg) IU to $50,000(1250 \mathrm{mcg})$ IU of vitamin $D$ a day}

In 2009 one author (PM) made it a standard of care to offer hospitalized patients either 5000 (125 $\mathrm{mcg}$ ) IU/day or 10,000 (250 mcg) IU/day after realizing the importance of maintaining vitamin D sufficiency in hospitalized patients who had no access to sunshine or UVB phototherapy, who were receiving very little vitamin $\mathrm{D}$ in their diets, and who often had undetectable or extremely low serum 25(OH)D concentrations in their blood [142]. This occurred at the Daniel Drake Center for Post-Acute Care in Cincinnati, Ohio. The protocol established by Dr Heaney in 2003 was adopted, when he showed using these daily intakes to be safe over a 5-month period [129], as discussed earlier. This practice continued as a standard of care after the author moved to Summit Behavioral Healthcare in 2011, where a significant prevalence of vitamin D deficiency was also noted and continues to exist on new admissions to the facility [59].

On April 7th, 2020 we had census of 288 patients at our hospital, of which 254 (88.2\%) were taking a vitamin D supplement. Of patients taking vitamin D, 193 (76\%) were taking 10,000 (250 mcg) IU/day, while $51(20.5 \%)$ were taking $5000(125 \mathrm{mcg}) \mathrm{IU} /$ day, and $9(3.6 \%)$ were taking higher doses. This is a typical profile for the past 9 years. We have never seen vitamin D induced hypercalcemia, or any other complication related to vitamin $\mathrm{D}$ intake using these doses. Some of our patients are long term patients who have been taking these doses for several years. In patients receiving 10,000 (250 mcg) IU/day, the highest serum $25(\mathrm{OH}) \mathrm{D}$ concentration we have observed is $202 \mathrm{ng} / \mathrm{ml}$, with normal serum calcium and iPTH concentrations. We have found this regimen to be consistently safe, and recently published the 2019 report cited earlier giving insights from our experiences over the seven year period from 2011 to 2018. We have treated over several thousand hospitalized patients with this protocol over the past 11 years, and have observed no issues with hypercalcemia, or any other adverse events related to vitamin $\mathrm{D}$.

Several reports have shown that if hypercalcemia does occur, it is easily reversible with cessation of vitamin D intake, and supportive care if necessary. This was shown in the 1940s in patients with rheumatoid arthritis treated with 150,000 (3750 mcg) IU/day to $600,000(15,000 \mathrm{mcg}) \mathrm{IU} /$ day [70]. It was shown again in a 2011 vitamin D toxicity report when 2 individuals recovered uneventfully after one ingested over 970,000 (24,250 mcg) IU/day for 1 month, and the second ingested over 1.864 million (46,600 mcg) IU/day for 2 months [61]. Both cases occurred due to manufacturing and labeling errors in OTC supplements. The first individual had a peak serum $25(\mathrm{OH}) \mathrm{D}$ concentration of 645 $\mathrm{ng} / \mathrm{ml}$, and a serum calcium concentration of $13.2 \mathrm{mg} / \mathrm{dl}$. The second had a peak serum $25(\mathrm{OH}) \mathrm{D}$ concentration of $1220 \mathrm{ng} / \mathrm{ml}$, and a serum calcium concentration of $15.0 \mathrm{mg} / \mathrm{dl}$. The hypercalcemia was observed to resolve in both individuals when the serum $25(\mathrm{OH}) \mathrm{D}$ concentrations dropped below $400 \mathrm{ng} / \mathrm{ml}$.

As discussed in our earlier report [59], it is interesting to note that both Dowling [7] and Howard [70] in the 1940s observed random calcifications to occur at times in patients treated with large doses of vitamin D. Both scientists also observed that the calcifications and hypercalcemia resolved over time with cessation of vitamin D intake. The main treatment for vitamin D induced hypercalcemia appears to be stopping the vitamin D intake, and supportive care if needed. Once the serum $25(\mathrm{OH}) \mathrm{D}$ concentrations fall, the hypercalcemia improves, calcifications will dissolve if present, symptoms abate, and patients recover uneventfully $[7,61,70]$.

The data that we presented in our 2019 report is consistent with this, as we have not seen hypercalcemia develop in several individuals taking 25,000 (625 mcg) IU/day to 60,000 (1500 mcg) IU/day for several years. This is in spite of observing several serum $25(\mathrm{OH}) \mathrm{D}$ concentrations $>200$ $\mathrm{ng} / \mathrm{ml}$, and as high as $384 \mathrm{ng} / \mathrm{ml}$ in these individuals. We presented 3 case reports which included two of the authors, JA and PM, who have each been taking either 25,000 (625 mcg) IU/day (JA) or 60,000 (1500 mcg) IU/day (PM) for the past six years without complications while observing marked 
clinical improvement in asthma (JA) and in an ulcerated skin cancer (PM), as well as a patient with psoriasis treated with 50,000 (1250 mc) IU/day of vitamin D2 for over 2 years [59,137].

The average serum $25(\mathrm{OH}) \mathrm{D}$ concentrations we observed in patients taking 5000 (125 mcg) IU/day and 10,000 (250 mcg) IU/day for extended periods of time with serum $25(\mathrm{OH})$ D concentrations greater than $74.4 \mathrm{ng} / \mathrm{ml}$ were $102.9 \mathrm{ng} / \mathrm{ml}$ and $115.8 \mathrm{ng} / \mathrm{ml}$. For individuals taking $>10,000(250 \mathrm{mcg})$ $\mathrm{IU} /$ day in our report, the average serum $25(\mathrm{OH}) \mathrm{D}$ concentration was $234.6 \mathrm{ng} / \mathrm{ml}$, with no hypercalcemia noted, in spite of 3 of these individuals being on either 25,000 (625 mcg), 50,000 (1250 $\mathrm{mcg})$ or $60,000(1500 \mathrm{mcg})$ units per day for $>3$ years. The average serum calcium concentration when combining these 3 vitamin D groups ( $\mathrm{n}=418$ ) was $9.6 \mathrm{mg} / \mathrm{dl}$ (range 8.6 to $10.7 \mathrm{mg} / \mathrm{dl}$ ), compared to an average serum calcium concentration of $9.5 \mathrm{mg} / \mathrm{dl}$ (range 8.4 to $10.7 \mathrm{mg} / \mathrm{dl}$ ) in a group of patients not taking vitamin $\mathrm{D}(\mathrm{n}=777)$, whose average serum $25(\mathrm{OH}) \mathrm{D}$ concentration was $27.1 \mathrm{ng} / \mathrm{ml}$, versus $118.9 \mathrm{ng} / \mathrm{ml}$ in the combined three vitamin D groups.

We have tested the hypothesis that lower doses than were used to treat asthma, psoriasis, RA and TB in the 1930s and 1940s would be clinically effective and able to reproduce clinical benefits observed in the 1930s and 1940s for several diseases closely linked to vitamin D deficiency. We chose to use doses in the physiological range of $10,000(250 \mathrm{mcg}) \mathrm{IU} /$ day to $25,000(625 \mathrm{mcg}) \mathrm{IU} /$ day, and up to 60,000 (1500 mcg) IU/day. Although it is a small number and several cases are anecdotal, several individuals with asthma, psoriasis, Crohn's disease, Grave's disease, MS, lichen planus and RA have seen and maintained significant clinical improvement taking daily doses of vitamin $\mathrm{D}$ in this range. No one has reported developing hypercalcemia or needed to stop intake of vitamin D for any reason. Individuals with asthma, psoriasis and Crohn's disease reported disease exacerbation after stopping vitamin D intake, and improvement with resumption of intake. The effects on psoriasis and asthma are not anecdotal. Psoriatic plaques were monitored clinically for extended periods of time, as were the number of exacerbations and use of oral steroids and antibiotics in asthma, along with serum 25(OH)D, calcium and iPTH concentrations.

A recently reported clinical trial in asthma patients using $4000(100 \mathrm{mcg}) \mathrm{IU}$ of vitamin $\mathrm{D}_{3} /$ day following a 100,000 (2500 mcg) IU bolus ( $n=201)$ versus placebo $(n=207)$ over 24 months showed no improvement in asthma control [143]. The patients were deficient at baseline, with mean serum $25(\mathrm{OH}) \mathrm{D}$ concentrations of $18.8 \mathrm{ng} / \mathrm{l}$. The mean serum $25(\mathrm{OH}) \mathrm{D}$ concentrations remained $<20 \mathrm{ng} / \mathrm{ml}$ in the placebo group, while rising to $42 \mathrm{ng} / \mathrm{ml}$ (range 6.2 to $97.3 \mathrm{ng} / \mathrm{ml}$ ) by week 12 in the treatment group and persisted at this value through week 28 . In contrast, our experience has consistently shown that $10,000(250 \mathrm{mcg}) \mathrm{IU} /$ day to $25,000(625 \mathrm{mcg}) \mathrm{IU} /$ day is effective in safely treating asthma and achieves much higher serum $25(\mathrm{OH}) \mathrm{D}$ concentrations, although involving only a small number of people to date. As noted above, we previously described JA's experience with asthma and vitamin D [59]. He began taking 10,000 (250 mcg) IU of vitamin $\mathrm{D}_{3} /$ day in 2011 , and has only had one significant attack since then, when he dropped the dose early on to 5000 (125 mcg) IU/day. He has been taking 25,000 (625 mcg) IU a day for several years now without complication and has not required oral steroids for management. His serum $25(\mathrm{OH}) \mathrm{D}$ concentrations have ranged from $96.6 \mathrm{~g}$ $\mathrm{ng} / \mathrm{ml}$ to $161 \mathrm{ng} / \mathrm{ml}$, with normal serum calcium and intact parathyroid hormone concentrations. Prior to taking 10,000 (250 mcg) IU daily he was prescribed oral steroids several times a year and would miss several days of work with each severe exacerbation. He has used albuterol for mild exacerbations related to bronchitis and does continue to take Symbicort daily. The failure of the asthma trial and the success of our small sample sizes with various diseases is consistent with the increased number of genes shown to be regulated with increasing daily intake of vitamin $\mathrm{D}$ as discussed earlier [55].

We have observed several psoriasis patients achieve excellent control of their plaques within three to four months taking daily doses of 40,000 (1000 mcg) IU of vitamin D3 [84] and 50,000 (1250 $\mathrm{mcg}$ ) IU of vitamin $\mathrm{D}_{2}$ for over three years while maintaining normal serum calcium and iPTH concentrations [59]. These findings fit with those of another group of investigators who reported in 2013 similar safety and efficacy using 35,000 (875 mcg) IU/day of vitamin $\mathrm{D}_{3}$ for 6 months in 25 patients with either psoriasis or vitiligo [85]. A group looking into vitamin D supplement dosing and serum $25(\mathrm{OH}) \mathrm{D}$ concentrations in the range associated with cancer prevention have suggested that 
daily intake of 40,000 (1000 mcg) IU of $\mathrm{D}_{3}$ is likely to be safe [138], also consistent with our experiences. They also found extended daily intake with 10,000 $(250 \mathrm{mcg})$ safe. Other investigators have reported similar findings. A pancreatic cancer case report in 2016 showed a remarkable clinical benefit in a patient who took 50,000 (1250 mcg) IU/day for 9 months [139]. A Parkinson's disease case report from 1997 showed remarkable clinical benefits in a patient who had progressively worsening disease over a 13 year period a year after treatment with 4000 IU/day of 25OHD3 (roughly equivalent to 20,000 (500 mcg) IU/day of $\mathrm{D}_{3}$ [145]) for a year [140].

In 2017 a study in pregnancy reported that achieving maternal serum $25(\mathrm{OH}) \mathrm{D}$ concentrations $\geq 40 \mathrm{ng} / \mathrm{mL}$ early in pregnancy was associated with $60 \%$ lower preterm birth risk among general obstetrical patients at an urban medical center. Many pregnant women were found to have serum $25(\mathrm{OH}) \mathrm{D}$ concentrations $<20 \mathrm{ng} / \mathrm{ml}$, which is significantly associated with increased risk for complications of pregnancy, including preterm birth [145]. In 2018 a pooled analysis of two randomized trials and a prospective cohort found serum $25(\mathrm{OH}) \mathrm{D}$ concentrations above $60 \mathrm{ng} / \mathrm{ml}$ were associated with a markedly lower risk for breast cancer compared to $25(\mathrm{OH}) \mathrm{D}$ concentrations less than $20 \mathrm{ng} / \mathrm{ml}[146]$.

\section{Racial disparities in serum $25(\mathrm{OH}) \mathrm{D}$ concentrations - could this explain the alarming death rate among non-Hispanic (NH) blacks infected with coronavirus?}

Two recent surveys on vitamin D deficiency (VDD) and vitamin D insufficiency (VDI) were performed on the US population and reported in 2009 [62] and in 2018 [63]. Both surveys were performed due to the realization that both VDD and VDI are strongly linked to increased risk for multiple medical problems including cardiovascular disease, cancer, infections, diabetes, hypertension, all-cause mortality, MS, RA and other autoimmune diseases, and that vitamin D supplementation and higher serum $25(\mathrm{OH}) \mathrm{D}$ concentrations were associated with reduced risk for these diseases. Both surveys used data from the National Health and Nutrition Examination Surveys (NHANES) data base.

The 2009 survey used NHANES III data from 1988 through 1994 and compared this with results from NHANES data collected from 2001 to 2004. The 2018 report looked at NHANES data from 2001 through 2010. The NHANES data was used as a representative sampling of the US population. Multiple factors that might influence serum 25(OH)D concentrations were examined in both reports, including race.

A total of 18,883 participants were used in NHANES III, and 13,369 in NHANES 2001 to 2004. In NHANES III there were 5362 non-Hispanic (NH) blacks (11\%), $7428 \mathrm{NH}$ whites (75\%), 5305 Mexican American (6\%), and 788 other (8\%). In NHANES 2001 to 2004 There were 3149 NH blacks (11\%), 6131 NH whites (72\%), 3211 Mexican American (8\%), and 878 other (9\%). In the NHANES 2001 to 2010 data a total of 26,010 adults 18 years and older were used, which included $6968 \mathrm{NH}$ blacks $(10.7 \%), 12,770 \mathrm{NH}$ whites (71.1\%), 5164 Hispanics (12.7\%), and a group labeled other.

In 2009 a normal serum 25(OH)D concentration was considered to be $>30 \mathrm{ng} / \mathrm{ml}$. In the 2009 report, the mean serum 25(OH)D concentrations were found to be $30 \mathrm{ng} / \mathrm{ml}$ during 1988 to 1994 and decreased to $24 \mathrm{ng} / \mathrm{ml}$ between 2001 to 2004 . The prevalence of serum $25(\mathrm{OH}) \mathrm{D}$ concentrations < $10 \mathrm{ng} / \mathrm{ml}$ increased from $2 \%$ to $6 \%$, while the prevalence of values $<20 \mathrm{ng} / \mathrm{ml}$ increased from $22 \%$ to $36 \%$ between the two time frames.

In NH blacks, the prevalence of serum $25(\mathrm{OH}) \mathrm{D}$ concentrations $<10 \mathrm{ng} / \mathrm{ml}$ increased from $9 \%$ to $29 \%$, indicating a much greater degree of VDD. The prevalence of serum $25(\mathrm{OH}) \mathrm{D}$ concentrations < $20 \mathrm{ng} / \mathrm{ml}$ was not provided. There was also a marked decrease in the prevalence of serum $25(\mathrm{OH}) \mathrm{D}$ concentrations $>30 \mathrm{ng} / \mathrm{ml}$, dropping from $45 \%$ to $23 \%$ in the two time periods. In NH blacks the prevalence of values $>30 \mathrm{ng} / \mathrm{ml}$ decreased from $12 \%$ to $3 \%$. The authors noted that $97 \%$ of NH blacks and $90 \%$ of Hispanics were $<30 \mathrm{ng} / \mathrm{ml}$. These investigators concluded that decreased sun exposure, increased use of sunscreens, decreased outdoor activity and obesity were likely the main factors contributing to this problem. They suggested increased sun exposure and increased vitamin D supplementation would likely improve the vitamin D status and the overall health of the US population. They also stated, "our data provide additional evidence that current recommendations 
for vitamin D supplementation (220 to $600 \mathrm{IU} / \mathrm{d}$ ) are inadequate to achieve optimal serum 25(OH)D concentrations in most of the US population [62] (p. 6)."

In the 2018 report the criteria used to define VDD and VDI were adopted from the Endocrine Society [58]. VDD deficiency was defined as serum 25(OH)D concentrations $<20 \mathrm{ng} / \mathrm{ml}$. VDI was defined as serum $25(\mathrm{OH}) \mathrm{D}$ concentrations $<30 \mathrm{ng} / \mathrm{ml}$ but $>20 \mathrm{ng} / \mathrm{ml}$.

Using these criteria, the prevalence of VDD was found to be $28.9 \%$ and VDI was $41.4 \%$ in the 2001 to 2010 time period and did not change significantly over time. Older age, physical inactivity, obesity, rare milk consumption and being black were found to be the highest risk factors for developing VDD. The percentage of individuals with serum $25(\mathrm{OH}) \mathrm{D}$ concentrations $>50 \mathrm{ng} / \mathrm{ml}$ was $1.7 \%$, and only $0.38 \%$ had serum $25(\mathrm{OH}) \mathrm{D}$ concentrations $>60 \mathrm{ng} / \mathrm{ml}$.

$\mathrm{NH}$ blacks were again found to have the highest prevalence of VDD among racial groups at $71.9 \%$, compared to $42.8 \%$ for Hispanics, $18.6 \%$ for NH whites, and $46.1 \%$ for other races. The highest prevalence of VDI was $43.7 \%$ in Hispanics, followed by $43.6 \%$ in NH whites, $38.8 \%$ in other races, and $22.6 \%$ in NH blacks. NH blacks were found to have serum $25(\mathrm{OH}) \mathrm{D}$ concentrations $9 \mathrm{ng} / \mathrm{ml}$ lower than $\mathrm{NH}$ whites, while Hispanics had serum $25(\mathrm{OH}) \mathrm{D}$ concentrations $4 \mathrm{ng} / \mathrm{ml}$ lower than $\mathrm{NH}$ whites. The fact that $71.9 \%$ of $\mathrm{NH}$ blacks are estimated to have serum $25(\mathrm{OH}) \mathrm{D}$ concentrations $<20 \mathrm{ng} / \mathrm{ml}$, while $29 \%$ were $<10 \mathrm{ng} / \mathrm{ml}$ in the 2009 report is a call for action, as these serum $25(\mathrm{OH}) \mathrm{D}$ concentrations are unable to effectively sustain production of antimicrobial peptides in response to infections, and could provide one explanation for why COVID-19 is killing NH blacks at an alarming rate [64] and has been twice as deadly for both $\mathrm{NH}$ blacks and Latinos as compared to whites in New York City [65].

\section{Discussion}

Tuberculosis studies in the 1940s proved that vitamin D was effective at killing not only mycobacterium tuberculosis but also other microorganisms such as proteus vulgaris, bacillus aerogenes, staphylococci and non-hemolytic streptococci [4-11]. Sixty years later the mechanisms of action were determined. After cells sense microorganisms via toll-like receptors on their surface a signal transduction pathway is activated, causing intracellular production of calcitriol and VDR, leading to production of antimicrobial peptides. Thus our innate immune system can essentially make antimicrobials on demand, and vitamin $\mathrm{D}$ is the switch that turns on the production.

Many different cell types have been reported capable of making antimicrobial peptides in response to sensing microorganisms by upregulating vitamin D regulated genes, and several different types of antimicrobial peptides have been identified, including cathelicidin, alpha defensins, beta defensins, S100 proteins, ribonucleases (RNases) and dermcidin. These antimicrobial peptides are reported to exhibit a wide range of activity against a host of microorganisms. In the past 2 decades the list of microorganisms that vitamin $\mathrm{D}$ is effective against has grown to include several viruses including rotavirus, respiratory syncytial virus, Kaposi Sarcoma-Associated Herpesvirus, dengue virus and possibly HIV. All of this occurs indirectly via the actions of the antimicrobial peptides that vitamin $\mathrm{D}$ causes to be produced in its action as a steroid hormone.

In addition to their killing activities, antimicrobial peptides also display immunomodulatory properties, including induction of cell migration, proliferation and differentiation; regulation of cytokine/chemokine production; promotion of angiogenesis and wound healing; and maintenance of the barrier function of the skin. Thus, they have functions beyond their antimicrobial activities that are also important to maintaining human health.

In the 1930s and 1940s oral vitamin D was shown effective in treating several diseases with much higher intakes than are in use today, and which are also significantly higher than amounts made in the skin in response to 1 MED of UVB radiation:

1. Asthma was controlled with $60,000(1500 \mathrm{mcg}) \mathrm{IU} /$ day to $300,000(7500 \mathrm{mcg}) \mathrm{IU} /$ day.

2. TB was cured with $100,000(2500 \mathrm{mcg}) \mathrm{IU} /$ day to $150,000(3750 \mathrm{mcg}) \mathrm{IU} /$ day for 2 to 3 months with no toxicity.

3. RA was controlled with 150,000 (3750 mcg) IU/day to 600,000 (15,000 mcg) IU/day.

4. Psoriasis was controlled with about $20,000(500 \mathrm{mcg}) \mathrm{IU} /$ day. 
5. Rickets was cured with a few hundred IU/day.

Why investigators in those times chose to use these doses is unclear. Estimates of the amounts of vitamin D produced in the skin were unknown at that time, and would not be reported until the 1977, when it was shown that the body makes over 10,000 (250 mcg) IU/day in response to sun exposure to the skin [144], with this estimate increasing to 25,000 (625 mcg) IU/day in the 1980s [58]. While pioneering investigators realized that the doses of vitamin D that they were using in the 1930s and 1940s were potentially toxic, it is not clear why they did not titrate the doses down to see if lower doses would still be clinically effective, without causing hypercalcemia. This may be related to the fact that some people on these high doses died and vitamin D was thought to be the causative agent, although it is not clear how many deaths were caused by vitamin D [7,69-70]. Without performing dose titration studies, the recommended daily intake of vitamin $\mathrm{D}$ was reduced to a few hundred IU/day, as this was shown to be an effective dose for treating rickets [147], and essentially remains there today. There is a compelling argument that the dose titration studies not performed in the 1940s need to be done today.

The Endocrine Society's closing statement addresses this issue from the opposite vantage point, as they argued for clinical trials using higher daily intakes of vitamin D than are currently in use: "randomized clinical trials that evaluate the effects of vitamin D doses in the range of 2000-5000 IU/d on non-calcemic health outcomes are desperately needed. There is no evidence that there is a downside to increasing vitamin $\mathrm{D}$ intake in children and adults, except for those who have a chronic granuloma-forming disorder or lymphoma [58] (p. 23)." We propose expanding this testing to include vitamin D intakes in the range of $10,000(250 \mathrm{mcg}) \mathrm{IU} /$ day to $25,000(625 \mathrm{mcg}) \mathrm{IU} / \mathrm{day}$. The implications for human health are potentially enormous, especially during the current pandemic that we are experiencing.

Dr Heaney and colleagues reported in 2003 that daily intake of $836(20.9 \mathrm{mcg})$ IU/day for 5 months had a negligible impact on serum $25(\mathrm{OH}) \mathrm{D}$ concentrations, increasing the baseline concentration of $28 \mathrm{ng} / \mathrm{ml}$ to $33 \mathrm{ng} / \mathrm{ml}$, while $11,000(275 \mathrm{mcg}) \mathrm{IU} /$ day was safe, and caused a significant increase to $88 \mathrm{ng} / \mathrm{ml}$ [129]. Our group has been following his protocol for the past 11 years as a standard of care without issue and have treated several thousand patients with $5000(125 \mathrm{mcg})$ IU/day or 10,000 (250 mcg) IU/day without any complications [59]. Moreover, we and others have also had no clinically significant issues while observing significant clinical benefits in people with asthma, psoriasis, cancer, Crohn's disease, Grave's disease, MS, Parkinson's disease, vitiligo, and lichen planus when extending the dosing to 20,000 (500 mcg) to 60,000 (1500 mcg) IU/day, albeit in much smaller numbers of patients. As it is known from VDR pharmacology that there is a definite dose response in the number of vitamin $D$ regulated genes that are up- or down- regulated, with eight times as many genes affected with 10,000 ( $250 \mathrm{mcg}$ ) IU/day ( $\mathrm{n}=1289$ genes) vs 600 (15 mcg) IU/day $(n=162$ genes) and 4 times as many genes vs $4000(100 \mathrm{mcg})$ IU/day $(n=320)$ after 6 months of daily intake [55], there is a basis for supplementation of vitamin D with supratherapeutic doses. Importantly, case and anecdotal reports of high-dose vitamin D supplementation provide premise for further examination using formal clinical trials.

We hypothesize based upon our current understanding of VDR pharmacology that current recommendations to take only $600(15 \mathrm{mcg}) \mathrm{IU} /$ day, or even $4000(100 \mathrm{mcg}) \mathrm{IU} /$ day in people who are already severely VDD, such as non-Hispanic blacks, will not be sufficient to support the increased need for serum $25(\mathrm{OH}) \mathrm{D}$ when cells are overwhelmed with a sudden surge of microorganisms and respond by trying to turn on production of vitamin $\mathrm{D}$ regulated antimicrobial peptide genes. The current recommended levels of supplementation do not appear to generate enough serum $25(\mathrm{OH}) \mathrm{D}$ to support this protective, if not potentially life-saving response.

\section{Conclusions}

When considering the risk to benefit ratio of a treatment, when the potential benefits of a treatment significantly outweigh the risks, then recommending a treatment during a pandemic like we are currently experiencing with so many lives at risk seems warranted. The risk of remaining vitamin D deficient and being unable to mount an effective antimicrobial peptide response proven to 
be regulated by vitamin $\mathrm{D}$, far outweighs the risk of possibly developing toxicity related to hypercalcemia caused by excessive vitamin $\mathrm{D}$ intake.

This is especially true when hypercalcemia caused by excessive vitamin D intake has consistently been shown to be reversible with cessation of vitamin D intake without any long-term sequelae. The development of hypercalcemia can also be easily monitored and prevented by periodic blood tests measuring serum calcium, 25(OH)D and intact parathyroid hormone concentrations. Studies suggest that this untoward effect will not likely occur after taking 10,000 (250 mcg) IU/day for extended periods of time.

Vitamin D deficiency is a significant risk factor for the development of acute respiratory tract infections, as well as many other diseases. While vitamin D may not ultimately prove to be active against coronavirus, the resulted augmented host defense generated will be active against a number of other microorganisms that may potentially cause deadly opportunistic infections as a result of the coronavirus infection. The daily intake and amount of vitamin D required in the blood to support sustained AMP production against infectious microorganisms is currently unknown but is likely to be in the range of 10,000 ( $250 \mathrm{mcg}$ ) IU/day to 25,000 (625 mcg) IU/day.

The literature does not support hazards but instead significant advantages if the population could rapidly achieve and maintain robust serum $25(\mathrm{OH}) \mathrm{D}$ concentrations. It is known that the body generates $10,000(250 \mathrm{mcg}) \mathrm{IU} /$ day to $25,000(625 \mathrm{mcg}) \mathrm{IU} /$ day of vitamin D in the photosynthetic response to sunshine without causing hypercalcemia, while effectively treating tuberculosis infections, rickets and psoriasis plaques. Studies including our own extensive clinical experience over the past 11 years indicate these doses to be well-tolerated and safe, as well as inexpensive. Hence, we highly recommend that consideration be given for vitamin D supplementation in this range now to potentially protect people from the coronavirus. This is true for all populations but is especially true for African Americans, who are the most severely vitamin D deficient and who are suffering disproportionately worse outcomes from coronavirus infections.

Current low-dose supplementation recommendations (600 (15 mcg) IU/day to 4000 (100 mcg) IU/day) appear to be insufficient to meet the goal of mounting a sustained protective host immune response including AMP production in the face of an overwhelming infection such as coronavirus.

The risk to benefit ratio, low expense, and broad availability clearly favor the use of vitamin D in doses of at least $10,000(250 \mathrm{mcg}) \mathrm{IU} /$ day in adults during the deadly coronavirus pandemic that now confronts much of the world, while lower doses may be sufficient in younger people. Treatment with supra-recommended doses of vitamin D may save lives and prevent needless suffering, with very little downside risk. Hence, the potential benefits of this cost-effective intervention appear to clearly outweigh the risks. Our collective experience and analysis of the peer-reviewed vitamin D literature supports this conclusion.

Acknowledgements: We wish to dedicate this work to the memory of the late Dr Robert P Heaney for his insight, guidance and advice. He was truly a leader in the field of vitamin D research and physiology, and an excellent mentor and teacher. We would also like to acknowledge Dr. William B Grant, Director, Sunlight, Nutrition and Health Research Center, San Francisco, California for his advice in preparing the manuscript.

Author Contributions: Conceptualization, P.J.M.; methodology, P.J.M.; writing-original draft preparation, P.J.M, D.S.L., W.P.M., J.B.T.; writing - review and editing, P.J.M, J.A., D.S.L., W.P.M., J.B.T., S.J.R.; supervision, P.J.M. All authors have read and agreed to the published version of the manuscript. Authorship must be limited to those who have contributed substantially to the work reported.

Conflict of Interest: The authors report no conflicts of interest.

Funding: These studies were funded in part by grants from the National institutes of Health grant R01 HL062996 (JBT), and Veteran's Administration Merit Award 5I01BX000853 (JBT). 


\section{References}

1.Tavera-Mendoza, L.E.; White, J. Cell defenses and the sunshine vitamin. Sci. Am. (November) (2007) 62-72.

2. Norman, A. Minireview: vitamin d receptor: new assignments for an already busy receptor. Endocrinology 147 (12) (2006) 5542-5548.

3. Norman, A.; Bouillon, R. Vitamin D nutritional policy needs a vision for the future. Exp. Biol. Med. 235 (2010) 1034-1045.

4. Raab, W. Vitamin D - its bactericidal action. Chest 12 (1946) 409-415.

5. Dowling, G.B.; Prosser Thomas, E.W. Lupus vulgaris treated with calciferol. Proc. R. Soc. Med. 39 (December) (1945) 96-99.

6. Dowling, G.B; Prosser Thomas, E.W.; Wallace, H.J. Lupus vulgaris treated with calciferol. Proc. R. Soc. Med. 39 (March) (1946) 225-227.

7. Dowling, G.B; Prosser, E.W. Treatment of lupus vulgaris with calciferol. Lancet 22 (June) (1946) 919-922.

8. Grant, G.A. Treatment of Lupus Vulgaris by Calciferol. British Medical Journal, Sep 14, 1946, 403.

9. Michelson, H.E.; Steves, R.J. Treatment of cutaneous tuberculosis with large doses of vitamin D. Arch. Derm. Syphilol. 56 (3) (1947) 317-324.

10. Tomlinson, K.M. Calcium content of skin in lupus vulgaris treated with Calciferol. Lancet 251 (1948) 327-328.

11. McCullough, P.J.; Lehrer, D.S. Vitamin D, cod liver oil, sunshine and phototherapy: safe, effective and forgotten tools for treating and curing tuberculosis infections - a comprehensive review. J. Steroid Biochem. Mol. Biol. 177 (2018) 21-29.

12. Williams, C.J.B. On the use and administration of cod-liver oil in pulmonary consumption. Lond. J. Med. (January (1)) (1849) 1-14.

13. Morner, K.A.H. Nobel Prize for Physiology or Medicine Award Ceremony Speech. Dec. 10, 1903. Available at (1903) http://www.nobelprize.org/nobel_prizes/ medicine/laureates/1903/press.html.

14. Biography of Dr Neils Ryberg-Finsen. https://www.nobelprize.org/nobel_prizes/ medicine/laureates/1903/finsen-bio.html.

15. Aitken, R. Lupus vulgaris* with special reference to its treatment with the finsenlomholt lamp. Br. Med. J. 23 (January) (1937) 160-163.

16. Van Der Lugt, L.; Rottier, P.B. Finsen therapy and vitamin D. Acta Dermato- Venerologica 38 (1958) 264-273.

17. Gotzsche, P.C. Niels Finsen's treatment for lupus vulgaris. J. R. Soc. Med. 104 (2011) 41-42.

18. Masten, A. Tuberculosis of the Lungs (A Booklet for the Patient). Colorado State Board of Health Bulletin, 1936, pp. 1-14 December.

19. Masten, A. Good climate - an asset in the treatment of tuberculosis. Chest 3 (7) (1937) 20-21.

20. Wang, T.T.; Nestel, F.P.; Bourdeau, V.; Nagai, Y.; Wang, Q.; Liao, J.; Tavera-Mendoza, L.; Lin, R.; Hanrahan, J.H.; Mader, S.; White, J.H. Cutting Edge: 1,25-Dihydroxyvitamin D3 Is a Direct Inducer of Antimicrobial Peptide Gene Expression. J of Immunol, 2004, 173: 2909-2912.

21. Gombart, A.F.; Borregaard, N.; Koeffler, H.P. Human cathelicidin antimicrobial peptide (CAMP) gene is a direct target of the vitamin $\mathrm{D}$ receptor and is strongly up-regulated in myeloid cells by 1,25-dihydroxyvitamin D3. FASEB J. 19, 1067-1077 (2005).

22. Weber G.; Heilborn J.D.; Chamorro Jimenez C.I.; Hammarsjo A.; Torma H.; Stahle M. Vitamin D induces the antimicrobial protein hCAP18 in human skin. J. Invest. Dermatol 2005;124(5):10801082. [PubMed: 15854055].

23. Liu, P.T.; Stenger, S.; Li, H.; et al., Toll-like receptor triggering of a vitamin D Mediated human antimicrobial response. Science 311 (2006) 1770-1773.

24. Hata, T.R.; Kotol, P.; Jackson, M.; Nguyen, M.; Paik, A.; Udall, D.; et.al, Administration of oral vitamin D induces cathelicidin production in atopic individuals. J Allergy Clin Immunol. 2008 October; 122(4): 829-831. doi: 10.1016/j.jaci.2008.08.020. 
25. Gombart, A. The vitamin D-antimicrobial peptide pathway and its role in protection against infection. Future Microbiol. Nov 2009; 4:1151. Doi:10.2217/fmb.09.87.

26. Guaní-Guerra, E.; Santos-Mendoza, T.; Lugo-Reyes, S.O.; Terán, L.M. Antimicrobial peptides: General overview and clinical implications in human health and disease. Clin. Immunol. (2010) 135, 1-11. doi: 10.1016/j.clim.2009.12.004.

27. White, J.H.; Vitamin D as an inducer of cathelicidin antimicrobial peptide expression: Past, present and future. J of Steroid Biochem. Mol. Biol. 121 (2010) 234-238.

28. Hertting, O.; Holm, A.; Lüthje, P.; Brauner, H.; Dyrdak, R.; Fianu Jonasson, A.; Wiklund, P.; Chromek, M.; Brauner, A. (2010) Vitamin D Induction of the Human Antimicrobial Peptide Cathelicidin in the Urinary Bladder. PLoS ONE 5(12): e15580. https://doi.org/10.1371/journal.pone.0015580.

29. Campbell, Y.; Fantacone, M.L.; Gombart, A.F. Regulation of antimicrobial peptide gene expression by nutrients and by-products of microbial metabolism. Eur J Nutr. 2012 December; 51(8): 899-907. doi:10.1007/s00394-012-0415-4.

30. Khare, D.; Godbole, N.M.; Pawar, S.D.; Mohan, V.; Pandey, G.; Gupta, S.; et. al., Calcitriol [1, $25[\mathrm{OH}] 2$ D3] pre- and post-treatment suppresses inflammatory response to influenza A (H1N1) infection in human lung A549 epithelial cells. Eur J Nutr (2013) 52:1405-1415 DOI 10.1007/s00394-0120449-7.

31. Currie, S.M.; Findlay, E.G.; McHugh, B.J.; Mackellar, A.; Man, T.; Macmillan, D.; et.al. The human cathelicidin LL-37 has antiviral activity against respiratory syncytial virus. PLoS One, 2013. 8(8): p. e73659.

32. Borella, E.; Nesher, G.; Israeli, E.; Shoenfeld, Y. Vitamin D: a new anti-infective agent? Ann N Y Acad Sci, 2014. 1317: p. 76-83. Ann. doi: 10.1111/nyas.12321.

33. Dimitrov, V.; White, J. Species-specific regulation of innate immunity by vitamin D signaling. J. Steroid Biochem. Mol. Biol. (2015), http://dx.doi.org/10.1016/j.jsbmb.2015.09.016.

34. Bucak, I.H.; Ozturk, A.B.; Almis, H.; Cevik, M.O.; et al., Is there a relationship between low vitamin D and rotaviral diarrhea? Pediatr Int, 2016. 58(4): p. 270-3.

35. Niyonsaba, F.; Kiatsurayanon, C.; Chieosilapatham, P. Friends or foes? Host defense (antimicrobial) peptides and proteins in human skin diseases. Experimental Dermatology, 2017;26:989-998. Doi: 10.1111/exd.13314.

36. Brice, D.C.; Toth, Z.; Diamond, G. LL-37 disrupts the Kaposi's sarcoma-associated herpesvirus envelope and inhibits infection in oral epithelial cells. Antiviral Res, 2018. 158: p. 25-33.

37. Laplana, M.; Royo, J.L.; Fibla, J. Vitamin D Receptor polymorphisms and risk of enveloped virus infection: A meta-analysis. Gene, 2018. 678: p. 384-394.

38. Giraldo, D.M.; Cardona, A.; Urcuqui-Inchima, S. High-dose of vitamin D supplement is associated with reduced susceptibility of monocyte-derived macrophages to dengue virus infection and proinflammatory cytokine production: An exploratory study. Clinica Chimica Acta 478 (2018) 140-151, https://doi.org/10.1016/j.cca.2017.12.044.

39. Alvarez, N.; Aguilar-Jimenez, W.; Rugeles, M.T. The Potential Protective Role of Vitamin D Supplementation on HIV-1 Infection. Front Immunol, 2019. 10: p. 2291.

40. Zhao, Y.; Ran, Z.; Jiang, Q.; Hu, N.; Yu, B.; Zhu, L.; Shen, L.; Zhang, S.; Chen, L.; Chen, H.; et al. Vitamin D Alleviates Rotavirus Infection through a Microrna-155-5p Mediated Regulation of the TBK1/IRF3 Signaling Pathway In Vivo and In Vitro. Int. J. Mol. Sci. 2019, 20, doi:10.3390/ijms20143562.

41. Martinez-Moreno, J.; Hernandez, J.C.; Urcuqui-Inchima, S. Effect of high doses of vitamin D supplementation on dengue virus replication, Toll-like receptor expression, and cytokine profiles on dendritic cells. Mol. Cell. Biochem. 2020, 464, 169-180, doi:10.1007/s11010-019-03658-w.

42. Chung, C.; Silwal, P.; Kim, I.; Modlin, R.L.; Jo, E.K. Vitamin D-Cathelicidin Axis in Immune Defense and Inflammation. Immune Netw. 2020 Apr;20(2):e12 https://doi.org/10.4110/in.2020.20.e12 pISSN 1598-2629·eISSN 2092-6685.

43. Gombart, A.F.; Pierre, A.; Maggini, S. A Review of Micronutrients and the Immune SystemWorking in Harmony to Reduce the Risk of Infection. Nutrients 2020, 12, 236, doi:10.3390/nu12010236. 
44. Norman, A.W. HORMONES I Steroid Hormones, Encyclopedia of Food Sciences and Nutrition (Second Edition) 2003, Pages 3166-3174, https://doi.org/10.1016/B0-12-227055-X/00606-4.

45. Pike, J.W. Genome-wide principles of gene regulation by the vitamin D receptor and it's activating ligand. Molecular and Cellular Endocrinology 347 (2011) 3-10. Doi: 10.1016/j.mc3.2011.05.012.

46. Haussler, M.R., et al. Vitamin D receptor (VDR)-mediated actions of 1alpha, 25(OH)2vitamin D3: Genomic and non-genomic mechanisms. Best Practice \& Research Clinical Endocrinology \& Metabolism 25 (2011) 543-559.

47. Pike, J.W.; Christakos, S. Biology and Mechanisms of Action of the Vitamin D Hormone. Endocrinol. Metab. Clin. 2017, 46, 815-843, doi:10.1016/j.ecl.2017.07.001.

48. Grant, W.B.; Lahore, H.; McDonnell, S.L.; Baggerly, C.A.; French, C.B.; Aliano, J.L.; Bhattoa, H.P. Evidence that Vitamin D Supplementation Could Reduce Risk of Influenza and COVID-19 Infections and Deaths. Nutrients 2020, 12, 988; doi:10.3390/nu12040988.

49. Laviano, E.; Sanchez Rubio, M.; Gonzalez-Nicolas, M.T.; Palacian, M.P.; Lopez, J.; Gilaberte, Y.; Calmarza, P.; Rezusta, A.; Serrablo, A. Association between preoperative levels of 25hydroxyvitamin $\mathrm{D}$ and hospital-acquired infections after hepatobiliary surgery: A prospective study in a third-level hospital. PLoS ONE 2020, 15, e0230336, doi:10.1371/journal.pone.0230336. March 26, 2020.

50. Martineau, A.R.; Jolliffe, D.A.; Hooper, R.L.; Greenberg, L.; Aloia, J.F.; Bergman, P.; DubnovRaz, G.; Esposito, S.; Ganmaa, D.; Ginde, A.A.; et al. Vitamin D supplementation to prevent acute respiratory tract infections: Systematic review and meta-analysis of individual participant data. BMJ 2017, 356, i6583, doi:10.1136/bmj.i6583.

51. Martineau, A.R.; Jolliffe, D.A.; Greenberg, L.; Aloia, J.F.; Bergman, P.; Dubnov-Raz, G.; et.al., Vitamin D supplementation to prevent acute respiratory infections: individual participant data metaanalysis, Health Technol Assess 2019;23(2).

52. Salzberg, S. Open questions: How many genes do we have? BMC Biology (2018) 16:94 https://doi.org/10.1186/s12915-018-0564-x .

53. What is the human genome project. https://www.genome.gov/human-genomeproject/What).

54. Ramagopalan, S.V.; Heger, A.; Berlanga, A.J.; et al., A ChIP-seq defined genome-wide map of vitamin $\mathrm{D}$ receptor binding: associations with disease and evolution.

Genome Res. 20 (2010) 1352-1360.

55. Shirvani, A.; Kalajian, T.A.; Song, A.; Holick, M.F. Disassociation of Vitamin D's Calcemic Activity and Non-calcemic Genomic Activity and Individual Responsiveness: A Randomized Controlled Double-Blind Clinical Trial. Sci. Rep. 2019, 9, 17685, doi:10.1038/s41598-019-53864-1.

56. Dietary Reference Intakes for Calcium and Vitamin D. Report Brief. Nov 2010. Institute of Medicine.

57. IOM (Institute of Medicine). 2011. Dietary Reference Intakes for Calcium and Vitamin D. Washington, DC: The National Academies Press.

58. Holick, M.F.; Binkley, N.C.; Bischoff-Ferrari, H.A.; Gordon, C.M.; Hanley, D.A.; Heaney, R.P.; Murad, M.H.; Weaver, C.M.; Evaluation, treatment, and prevention of vitamin D deficiency: An Endocrine Society clinical practice guideline. J. Clin. Endocrinol. Metab. 2011, 96, 1911-1930, doi:10.1210/jc.2011-0385.

59. McCullough, P.J.; Lehrer, D.S.; Amend, J. Daily oral dosing of vitamin D3 using 5000 TO 50,000 international units a day in long-term hospitalized patients: Insights from a seven year experience. J. Steroid Biochem. Mol. Biol. 2019, 189, 228-239, doi:10.1016/j.jsbmb.2018.12.010. Epub 2019 Jan 4.

60. 10 surprising dangers of vitamins and supplements. Don't assume they're safe because they're 'all natural'. Consumer Reports magazine: September 2012. https://www.consumerreports.org/cro/magazine/2012/09/10-surprising-dangers-of-vitamins-andsupplements/index.htm 
61. Araki, T.; Holick, M.F.; Alfonso, B.D.; Charlap, E.; Romero, C.M.; Rizk, D.; Newman, L.G. Vitamin D Intoxication with Severe Hypercalcemia due to Manufacturing and Labeling Errors of Two Dietary Supplements Made in the United States. J Clin Endocrinol Metab 2011; 96(12): 3603-3608.

62. Ginde, A.A.; Liu, M.C.; Camargo, C.A. Demographic Differences and Trends of Vitamin D Insufficiency in the US Population. 1988-2004, Arch Intern Med. 2009 March 23; 169(6): 626-632. doi:10.1001/archinternmed.2008.604.

63. Liu, X.; Baylin, A.; Levy, P.D. Vitamin D deficiency and insufficiency among US adults: prevalence, predictors and clinical implications. British J of Nutrition (2018), 119, 928-936. doi:10.1017/S0007114518000491 .

64. The coronavirus is infecting and killing black Americans at an alarmingly high rate. 4/7/2020. https:/www.washingtonpost.com/nation/2020/04/07/coronavirus-is-infecting-killing-blackamericans-an-alarmingly-high-rate-post-analysis-shows/?arc404=true.

65. Virus Is Twice as Deadly for Black and Latino People Than Whites in N.Y.C. 4/8/2020. https://www.nytimes.com/2020/04/08/nyregion/coronavirus-race-deaths.html.

66. Holick, M.F. Vitamin D deficiency. N. Engl. J. Med. 2007, 357, 266-281, doi:10.1056/NEJMra070553.

67. Krafka, K. A Simple Treatment for Psoriasis. The J. of Clin and Laboratory Medicine. 1936; 21: 1147-1148.

68. Dreyer, I.; Reed, C. The Treatment of Arthritis with Massive Doses of Vitamin D. Archives of Physical Therapy, Vol 16, Sept 1935, p537-543.

69. Bevans, M.; Taylor, H. Lesions Following the use of Ertron in Rheumatoid Arthritis. Am J of Pathology, 1947 May; 23(3): 367-387.

70. Howard, J.E.; Meyer, R.J. Intoxication with vitamin D. J Clin Endocrinology. 1948;8(11): 895910 .

71. Morimoto, S.; Kumahara, K. A Patient with psoriasis cured by 1 alpha-hydroxyvitamin D3. Med J Osaka Univ. 1985; 35(3-4): 51-4.

72. Morimoto, S.; Yoshikawa, K.; Kozuka, T.; et al. An open study of vitamin D3 treatment in psoriasis vulgaris. British Journal of Dermatology. 1986; 115: 421-429.

73. Takamoto, S.; Onishi, T.; Moromoto, S.; et.al. Effect of 1 alpha-hydroxycholecalciferol on psoriasis vulgaris: a pilot study. Calcif Tissue Int. 1986; 39(6): 360-4.

74. Morimoto, S.; Onishi, T.; Imanaka, S.; et al. Topical administration of 1,25-dihydroxyvitamin D3 for psoriasis: report of five cases. Calcif Tissue Int. 1986;38:119-122.

75. Morimoto, S.; Yoshikawa, K.; Kozuka, T.; et al. Treatment of psoriasis vulgaris with oral 1 alpha,25-dihydroxyvitamin D3 - report of two cases. J Dermatol. 1987;14: 59-62.

76. Morimoto, S.; Yoshikawa, K. Psoriasis and vitamin D3. A review of our experience. Arch Dermatol. 1989;125: 231-234.

77. Holick, M.F.; Smith, E.; Pincus, S. Skin as the Site of Vitamin D Synthesis and Target Tissue for 1,25-Dihydroxyvitamin D3 Use of Calcitriol (1,25-Dihydroxyvitamin D3) for Treatment of Psoriasis. Arch Dermatol 1987;123: 1677-1683a.

78. Smith, E.L.; Pincus, S.H.; Donovan, L.; Holick, M.F. A novel approach for the evaluation and treatment of psoriasis. Oral or topical use of 1,25-dihydroxyvitamin D3 can be a safe and effective therapy for psoriasis. J Am Acad Dermatology 1988; 19:516-28.

79. Holick, M.F. Will 1,25-Dihydroxyvitamin D3, MC 903, and Their Analogues Herald a New Pharmacologic Era for the Treatment of Psoriasis? Arch Dermatol. 1989;125: 1692-1697.

80. Huckins, D.; Felson, D.; Holick, M.F. Treatment of Psoriatic Arthritis with Oral 1,25dihydroxyvitamin D3: A Pilot Study. Arthritis and Rheumatism, Vol. 33, No. 11 (November 1990): 1723-1727.

81. Perez, A.; Raab, R.; Chen, T.C.; Turner, A.; Holick, M.F. Safety and efficacy of oral calcitriol (1,25-dihydroxyvitamin D3) for the treatment of psoriasis. British Journal of Dermatology 1996; 134: 1070-1078. 
82. Lugo-Somolinos, A.; Sanchez, J.L.; Haddock, L. Efficacy of 1, alpha 25-dihidroxyvitamin D (Calcitriol) in the treatment of psoriasis vulgaris: an open study. Bol Assoc Med P R. 1990 Oct;82(10):450-3.

83. Ezquerra, G.M.; Regaña, M.S.; Millet. P.U. Combination of acitretin and oral calcitriol for treatment of plaque-type psoriasis. Acta Derm Venereol. 2007;87:449-450.

84. McCullough, P.J. Arnold-Long, M. Marked improvement in psoriasis skin lesions within 5 months in two patients after treatment with oral vitamin D3 in doses ranging from 10,000 international units (IU's) to 40,000 IUs daily. Poster Presentation.15th Vitamin D Workshop, Houston, Texas, 2012.

85. Finamor, D.C.; Sinigaglia-Coimbra, R.; Neves, L.C.M.; Gutierrez, M.; Silva, J.J.; Torres, L.D.; Surano, F.; Neto, D.J.; Novo, N.F.; Juliano, Y.; Lopes, A.C.; Coimbra, C.G. A pilot study assessing the effect of prolonged administration of high daily doses of vitamin $\mathrm{D}$ on the clinical course of vitiligo and psoriasis. Dermato-Endocrinology. 2013; 5:1, 222-234; January/February/March 2013. http://dx.doi.org/10.4161/derm.24808.

86. Samini, M.; Seirafi, H.; Eftekhari, H.R. Efficacy and safety of topical cholecalciferol, calcitriol, and calcipitol in the treatment of plaque psoriasis: a comparative study. Acta Medica Iranica. 1998; 36(1)19-27.

87. Takahashi, H.; Ibe, M.; Kinouchi, M.; et al. Similarly potent action of 1,25-dihydroxyvitamin D3 and its analogues, tacalcitol, calcipotriol, and maxacalcitol on normal human keratinocyte proliferation and differentiation. J Dermatol Sci. 2003 Feb; 31(1):21-8.

88. Lebwohl, M.; Menter, A.; Weiss, J.; et al. Calcitriol 3 microg/g ointment in the management of mild to moderate plaque type psoriasis: results from 2 placebo-controlled, multicenter, randomized double-blind, clinical studies. J Drugs Dermatol. 2007 Apr;6(4):428-35.

89. Gold, L.F. Calcitriol ointment: optimizing psoriasis therapy. J Drugs Dermatol. 2009 Aug;8(8 Suppl):s23-7.

90. Abramovitz, W. Calcitriol 3 microg/g ointment: an effective and safe addition to the armamentarium in topical psoriasis therapy. J Drugs Dermatol. 2009 Aug;8(8 Suppl):s17-22.

91. Kircik, L. Efficacy and safety of topical calcitriol 3 microg/g ointment, a new topical therapy for chronic plaque psoriasis. J Drugs Dermatol. 2009 Aug;8(8 Suppl):s9-16.

92. Gaal, J.; Lakos, G.; Zodoray P.; et al. Immunological and clinical effects of alphacalcidol in patients with psoriatic arthropathy: results of an open, follow-up pilot study. Acta Derm Venereol. 2009; 89:140-144.

93. O'Neill, J.L.; SR Feldman, S.R. Vitamin D analogue-based therapies for psoriasis. Drugs Today (Barc). 2010 May;46(5):351-60. doi: 10.1358/dot.2010.46.5.1473264.

94. Laws, P.M.; Young, H.S. Topical treatment of psoriasis. Expert Opin Pharmacother. 2010 Aug;11(12):1999-2009. doi: 10.1517/14656566.2010.492778.

95. Oquendo, M.; Abramovits, W.; Morrell, P. Topical vitamin D analogs available to treat psoriasis. Skinmed. 2012 Nov-Dec;10(6):356-60.

96. Lebwohl, M.; Preston, N.; Gottschalk, R.W. Impact of Baseline Disease Severity Over 26 and 52 Weeks of Treatment with Calcitriol Ointment $3 \mathrm{mcg} / \mathrm{g}$ in Patients with Mild-to-moderate Plaque Psoriasis. J Clin Aesthet Dermatol. 2012; 5(2):28-33.

97. Sawyer, L.; Samarasekera, E.J.; Wonderling, D.; Smith, C.H. Topical therapies for the treatment of localized plaque psoriasis in primary care: a cost-effectiveness analysis. Br J Dermatol. 2013 May;168(5):1095-105. doi: 10.1111/bjd.12261.

98. Matos, T.R.; Sheth, V. The symbiosis of phototherapy and photoimmunology. Clinics in Dermatology (2016), doi: 10.1016/j.clindermatol.2016.05.00.

99. Prystowsky, J.H.; Muzio, P.J.; Sevran, S.; Clemens, T.L. Effect of UVB phototherapy and oral calcitriol (1,25-dihydroxyvitamin D3) on vitamin D photosynthesis in patients with psoriasis. J Am Acad Dermatol 1996; 35:690-5.

100. Lehmann, B.; Genehr, T.; Knuschke, P.; Pietzsch, J.; Meurer, M. UVB-induced conversion of 7-dehydrocholesterol to 1alpha,25-dihydroxyvitamin D3 in an in vitro human skin equivalent model. J Invest Dermatol. 2001 Nov;117(5):1179-85. DOI: 10.1046/j.0022-202x.2001.01538.x. 
101. Hearn, R.M.R.; Kerr, A.C.; Rahim, K.F.; Ferguson, J.; Dawe, R.S. Incidence of skin cancers in 3867 patients treated with narrow-band ultraviolet B phototherapy. Br J Dermatol. 2008 Sep;159(4):931-5. doi: 10.1111/j.1365-2133.2008.08776.x.

102. Koek, M.; Buskens, E.; van Weelden, H.; Steegmans, P.H.A.; Bruijnzeel-Koomen, C.A.F.M.; Sigurdsson, V. Home versus outpatient ultraviolet B phototherapy for mild to severe psoriasis: pragmatic multicenter randomized controlled non-inferiority trial (PLUTO study). BMJ 2009; 338:b1542 doi: 10.1136/bmj.b1542.

103. Koek, M.; Sigurdsson, V.; van Weelden, H.; Steegmans, P.H.A.; Bruijnzeel-Koomen, C.A.F.M.;

Buskens, E. Cost effectiveness of home ultraviolet B phototherapy for psoriasis: economic evaluation of a randomized controlled trial (PLUTO study). BMJ 2010; 340:c1490 doi:10.1136/bmj.c1490.

104. Vahavihu, K.; Ala-Houhala, M.; Peric, M.; et al. Narrowband ultraviolet B treatment improves vitamin $\mathrm{D}$ balance and alters antimicrobial peptide expression in skin lesions of psoriasis and atopic dermatitis. Br J Dermatol. 2010 Aug;163(2):321-8. Doi: 10.1111/j.1365-2133.2010.09767.x. Epub 2010 Mar 17.

105. Menter, A.; Korman, N.J.; et al. "Guidelines of care for the management of psoriasis and psoriatic arthritis: section 5. Guidelines of care for the treatment of psoriasis with phototherapy and photochemotherapy." J Am Acad Dermatol 2010; 62:114-35.

106. Ryan, C.; Moran, B.; McKenna, M.J.; et al. The Effect of Narrowband UV-B Treatment for Psoriasis on Vitamin D Status during Wintertime in Ireland. Arch Dermatology 2010; 146, 8: 836-842.

107. Osmancevic, A.; Landin-Wilhelmsen, K.; Larko, O.; Wennberg, A.M.; Krogstad, A.L. Vitamin D production in psoriasis patients increases less with narrowband than with broadband ultraviolet B phototherapy. Photodermatology, Photoimmunology \& Photomedicine 2009; 25:112-123.

108. Osmancevic, A.; Landin-Wilhelmsen, K.; Larko, O.; Krogstad A.L. Vitamin D status in psoriasis patients during different treatments with phototherapy. Journal of Photochemistry and Photobiology B: Biology. 2010; 101:117-123.

109. Grzybowski, A.; Pietrzak, K. From patient to discoverer-Niels Ryberg Finsen (18601904) - the founder of phototherapy in dermatology. Clinics in Dermatology (2012)30, 451-455.

110. Honigsmann, H. History of phototherapy in dermatology. Photochem. \& Photobiol. Sci. 2012. DOI: 10.1039/c2pp25120e. www.rsc.org/pps.

111. Honigsmann, H. Phototherapy. J. Invest Dermatol. 2013; 133: E18-E20. doi:10.1038/skinbio.2013.180.

112. Takahashi, H.; Tsuji, H.; Ishida-Yamamoto, A.; Lizuka, H. Comparison of clinical effects of psoriasis treatment regimens among calcipotriol alone, narrowband ultraviolet B phototherapy alone, combination of calcipotriol and narrowband ultraviolet B phototherapy once a week, and combination of calcipotriol and narrowband ultraviolet B phototherapy more than twice a week. Journal of Dermatology 2013; 40: 424-427. doi: 10.1111/1346-8138.12102.

113. Wong, T.; Hsu, L.; Liao, W. Phototherapy in Psoriasis: A Review of Mechanisms of Action. J Cutan Med Surg. 2013; 17(1): 6-12.

114. Shors, A.; Williams, L.; Fishman, P. Cost of prevalent psoriasis. J AM Acad Dermatol. 2014;70(5 Suppl 1):ABBO.

115. Lim, H.W.; Silpa-archa, N.; Amadi, U.; et al. Phototherapy in dermatology: A call for action. J Am Acad Dermatol. 2015; 72(6):1078-1080. http://dx.doi.org/10.1016/j.jaad.2015.03.017.

116. Grzybowski, A.; Sak, J.; Pawlikowski, J. A brief report on the history of phototherapy. Clin Dermatol. 2016 Sep-Oct;34(5):532-7. doi: 10.1016/j.clindermatol.2016.05.002. Epub 2016 May 20.

117. Foerster, J.; Boswell, K.; West, J.; et al. Narrowband UVB treatment is highly effective and causes a strong reduction in the use of steroid and other creams in psoriasis patients in clinical practice. 2017. PLoS ONE 12(8): e0181813. https://doi.org/10.1371/journal.pone.0181813.

118. Reichrath, J.; Saternusa, R.; Vogta, T. Challenge and perspective: the relevance of ultraviolet (UV) radiation and the vitamin D endocrine system (VDES) for psoriasis and other inflammatory skin diseases. Photochem. Photobiol. Sci. 2017; 16; 433-444. DOI: 10.1039/c6pp00280c. 
119. Boswell, K.; Cameron, H.; West, J.; et al. Narrowband ultraviolet B treatment for psoriasis is highly economical and causes significant savings in cost for topical treatments. Br J Dermatol. 2018 Nov;179(5):1148-1156. doi: 10.1111/bjd.16716. Epub 2018 Jul 29.

120. Phototherapy. National Psoriasis Foundation. June 2018. https://www.psoriasis.org/aboutpsoriasis/treatments/phototherapy.

121. Lehmann, B. Role of the vitamin D3 pathway in healthy and diseased skin - facts, contradictions and hypotheses. Experimental Dermatology 2009; 18: 97-108.

122. Lehmann, B.; Meurer, M. Vitamin D metabolism. Dermatologic Therapy. 2010; 23(1), $2-$ 12.doi:10.1111/j.1529-8019.2009.01286.x

123. Kamangari, F. Koo, J.; Heller, M.; Lee, E.; Bhutani, T. Oral vitamin D, still a viable treatment option for psoriasis. J of Dermatological Treatment. 2013;24: 261-267. DOI: 10.3109/09546634.2011.643219.

124. Soleymani, T.: Hung, T.; Soung, J. The role of vitamin D in psoriasis: a review. Int J Dermatol. 2015 Apr;54(4):383-92. doi: 10.1111/ijd.12790. Epub 2015 Jan 20.

125. Wadhwa, B.; Relhan, V.; Kochar, A.M.; Garg, V.K. Vitamin D and skin diseases: A review. Indian J Dermatol Venereol Leprol. 2015 Jul-Aug;81(4):344-55. doi: 10.4103/0378-6323.159928.

126. Reichrath, J.; Zouboulis, C.C.; Vogt, T.; Holick, M.F. Targeting the vitamin D endocrine system (VDES) for the management of inflammatory and malignant skin diseases: An historical view and outlook. Rev Endocr Metab Disord. DOI 10.1007/s11154-016-9353-4. Springer Science+Business Media New York 2016. Published online: 22 July 2016.

127. Barrea, L.; Savanelli, M.C.; Somma, C.; Napolitano, M.; Megna, A.; Colao, S.; Savastano, S. Vitamin D and its role in psoriasis: an overview of the dermatologist and nutritionist. Rev. Endocr. Metab. Disord. 18 (2017) 195-205. https://doi.org/10.1007/ s11154-017-9411-6.

128. JoAnn E. Manson, J.E.; Cook, N.R.; Lee, I.M.; Christen, W.; Bassuk, S.S.; Mora, S.; et.al. Vitamin D Supplements and Prevention of Cancer and Cardiovascular Disease. N Engl J Med. 2019 Jan 3;380(1):33-44. doi: 10.1056/NEJMoa1809944. Epub 2018 Nov 10.

129. Heaney, R.P.; Davies, K.M.; Chen, T.C.; Holick, M.F.; Barger-Lux, M.J. Human serum 25hydroxycholecalciferol response to extended oral dosing with cholecalciferol. Am. J. Clin. Nutr. 2003, 77, 204-210, doi:10.1093/ajcn/77.1.204.

130. Institute of Medicine, Standing Committee on the Scientific Evaluation of Dietary Reference Intakes, Food and Nutrition Board. Vitamin D. Chapter 7. In: Dietary Reference Intakes for calcium, phosphorus, magnesium, vitamin D, and fluoride. Washington, DC: National Academy Press, 1997.

131 Hess, A.F.; Unger, L.J. The Cure of Infantile Rickets by Sunlight. JAMA, July 2, 1921, p39.

132 Rajakumar. K. Vitamin D, Cod-Liver Oil, Sunlight, and Rickets: A Historical Perspective. Pediatrics Vol 112, No. 2, Aug 2003, e132-e135.

133. Rappaport, B.Z.; Reed, C.I.; Hathaway, M.L.; Struck, H.C. The Treatment of Hay Fever and Asthma with Viosterol of High Potency. The Journal of Allergy, September 1935; 5(6): 541-553.

134. Roth, D.E.; Jones, A.B.; Prosser, C.; Robinson, J.L.; Vohra, S. Vitamin D receptor polymorphisms and the risk of acute lower respiratory tract infection in early childhood. J Infect Dis. 2008;197(5):676-680.

135. Qu, M.; Di, S.; Zhang, S.; Xia, Z.; Quan, G. Vitamin D receptor protects glioblastoma A172 cells against coxsackievirus A16 infection induced cell death in the pathogenesis of hand, foot, and mouth disease. Biochem Biophys Res Commun. 2017;493(2):952-956.

136. Li, Y-P.; Wang, M-Q.; Deng, H-L.; Li, M.; Zhang, X.; Dang, S-S.; Zhai, S. Association of polymorphisms on the vitamin $\mathrm{D}$ receptor gene with susceptibility to and severity of hand, foot, and mouth disease caused by coxsackievirus A16. J Med. Virol. 2020;92:271-8.

137. McCullough, P.J.; Amend, J. Results of daily oral dosing with up to 60,000 international units of vitamin D3 for 2 to 6 years in 3 adult males. J of Steroid Biochem. Mol. Biol. (2017), http://dx.doi.org/10.1016/j.jsbmb.2016.12.009.

138. Garland, C.G.; French, C.B.; Baggerly, L.L.; Heaney, R.P. Vitamin D Supplement Doses and Serum 25-Hydroxyvitamin D in the Range Associated with Cancer Prevention. Anticancer Research 2011; 31: 617-622. 
139. Cannon, T.L. Ford, J.; Hester, D.; Trump, D.L. The incidental use of high-dose vitamin D3 in pancreatic Cancer. Case Rep. Pancreat. Cancer 2 (1) (2016), https://doi.org/ 10.1089/crpc.2016.0003.

140. Derex, L.; Trouillas, P. Reversible parkinsonism, hypophosphoremia, and hypocalcemia under vitamin D therapy, Mov. Disord. 12 (July (4)) (1997) 612-613.

141. USP Verified Dietary Supplements. https://www.quality-supplements.org/verifiedproducts.

142. McCullough, P.J.; Heaney, R.P. Correction of vitamin D deficiency using sublingually administered vitamin D2 in a Crohn's disease patient with mal-absorption and a new ileostomy. J Steroid Biochem Mol Biol. 2017 Oct;173:211-214. doi: 10.1016/j.jsbmb.2016.12.021. Epub 2016 Dec 31.

143. Castro, M.; King, T.S.; Kunselman, S.J.; Cabana, M.D.; Denlinger, L.; Holguin, F.; et.al, Effect of Vitamin D3 on Asthma Treatment Failures in Adults with Symptomatic Asthma and Lower Vitamin D Levels: The VIDA Randomized Clinical Trial. JAMA. 2014 May; 311(20): 2083-2091. doi:10.1001/jama.2014.5052.

144. Stamp, T.C.B.; Haddad, J.G.; Twigg, C.A. Comparison of oral 25-hydroxycholecalciferol, vitamin $\mathrm{D}$, and ultraviolet light as determinants of circulating 25-hydroxyvitamin D. Lancet (June) (1977) 1341-1343.

145. McDonnell, S.L.; Baggerly, K.A.; Baggerly, C.A.; Aliano, J.L.; French, C.B.; et al. Maternal 25(OH)D concentrations $\geq 40 \mathrm{ng} / \mathrm{mL}$ associated with $60 \%$ lower preterm birth risk among general obstetrical patients at an urban medical center, PLoS One 12 (7) (2017) e0180483, , https://doi.org/10.1371/journal.pone.0180483.

146. McDonnell, S.L.; Baggerly, C.A.; French, C.B.; Baggerly, L.L.; Garland, C.F.; Gorham, E.D.; Hollis, B.W.; Trump, D.L.; Lappe, J.M. Breast cancer risk markedly lower with serum 25hydroxyvitamin D concentrations $>60 \mathrm{vs}<20 \mathrm{ng} / \mathrm{ml}(150 \mathrm{vs} 50 \mathrm{nmol} / \mathrm{L})$ : pooled analysis of two randomized trials and a prospective cohort, PLoS One 13 (June (6)) (2018) e0199265, , https://doi.org/10.1371/journal.pone. 0199265.

147. Parks, E.A. The therapy of rickets. JAMA 115 (5) (1940) 370-379. 